\title{
Sultan II. Abdülhamid Dönemi Balkanları Üzerine Bir Değerlendirme: Goltz Paşa'nın Balkan Meselesine Dair Görüşleri
}

\section{An Evaluation on the Balkans during the Sultan Abdulhamid II Period: The Views of Goltz Pasha on the Balkan Question}

Hidayet Kara ${ }^{\text {a,* }}$

a Dr. Öğr. Üyesi, Muş Alparslan Üniversitesi, Fen Edebiyat Fakültesi, Tarih Bölümü, 49100, Muş/Türkiye. ORCID: 0000-0001-9642-7890

\section{MAKALE BİLGISİ}

\section{Makale Geçmişi:}

Başvuru tarihi: 04 Kasım 2019

Düzeltme tarihi: 16 Ocak 2020

Kabul tarihi: 30 Ocak 2019

Anahtar Kelimeler:
Goltz Paşa,
Balkanlar,
Siyaset,
Milliyetçilik
Osmanlı Devleti.

ÖZ

\begin{abstract}
Sultan II. Abdülhamid tahta çıktığında, Balkanlar adeta barut fiçısını andırıyordu. Bir taraftan Balkan milletlerinin isyanları diğer taraftan bu isyanları siyasî bir araç olarak kullanan büyük devletler, Payitaht üzerinde baskı kuruyordu. Nitekim problemi savaş yoluyla çözmeye istekli olan Rusya'nın 1877 yılının ilkbaharında Osmanlı Devleti'ne savaş ilan etmesi, meseleyi farklı bir boyuta taşıdı. Savaş Osmanlı Devleti'nin Balkan topraklarının önemli bir kısmını kaybetmesiyle neticelendi. Sultan II. Abdülhamid 1877-1878 Osmanlı-Rus Harbi'nden sonra Balkanlarda mümkün mertebe savaşın çıkmamasına dönük bir siyaset takip etti. Bu bağlamda, Balkan milletlerinin ayrılıklarından yararlanarak bir denge siyaseti kurmaya çalıştı. Osmanlı Devleti'nin Balkan siyaseti hakkında görüşlerini belirten Goltz Paşa, Abdülhamid siyasetinin aksine diplomasinin ancak güç ile desteklenirse başarılı olacağını belirtiyordu. Bu çerçevede makalede Goltz Paşa'nın, Osmanlı Devleti'nin Balkan siyasetine dair görüşleri irdelenecektir.
\end{abstract}

\section{A B S T R A C T}

When Sultan Abdülhamid II ascended the throne, the Balkans looked like a powder keg. On the one hand, the rebellions of the Balkan nations, on the other hand, the great powers that used these rebellions as a political argument put pressure on the Payitaht. In fact, Russia's declaration of war to the Ottoman Empire in the spring of 1877, which was willing to solve this problem through war, took the issue to a different dimension. This war resulted in the loss of a significant part of the Balkan lands of the Ottoman Empire. After the Ottoman-Russian War of 1877-1878, Sultan Abdulhamid II pursued a policy to prevent war in the Balkans as much as possible. In this context, he tried to establish a balance policy by taking advantage of the dissimilarity of Balkan nations. Stating his views about Balkan politics of the Ottoman Empire, Goltz Pasha stated that unlike Abdulhamid politics, diplomacy would only be successful if supported by force. In this framework, the article will examine the views of Goltz Pasha on the Balkan policy of the Ottoman Empire.

\section{Giriş}

Balkan milletleri arasında millet ve milliyet fikrinin doğuşunda, Osmanlı Devleti’nin savaş alanlarında Batılı devletler karşısında güçlü konumunu kaybetmesi önemli ancak tek etken değildir. Esasında kültürel anlamda etnik kimliğin devamlılı̆̆ı Osmanlı Devleti’nin tebaaya bakış açısıyla doğrudan bağlantılıdır. Denilebilir ki Osmanlıların Balkan milletlerinin kültürel kimliklerini muhafaza etmelerini sağlayacak bir sistem kurmaları, on dokuzuncu yüzyılda ortaya çıkan etnik milliyetçi düşünceye yönelmelerinde önemli bir kültürel birikime imkân vermiştir. Karpat'ın değişiyle Osmanlı yönetiminin, çeşitli etnik grupların yerel düzeyde cemaat bağlılıklarını millet sistemiyle güçlendirirken, onların büyük bir cemaat olarak bütünleşmesine de katkı sağlamıştır. Bu durum kuşkusuz, bir taraftan taşradaki cemaatlerin kendi dinsel ve dilsel kültürleri çerçevesinde yaşamasını sağlayarak, on dokuzuncu yüzyılda ortaya çıkacak olan yeni tüccar ve aydın

\footnotetext{
* Sorumlu yazar/Corresponding author

e-posta: h.kara36@hotmail.com
} 
sınıfı vasıtasıyla ulusal bir kimliğin ortaya çıkışına zemin hazırlamıştır (Karpat 2004: 67).

Osmanlı Devleti'nin tedrici olarak liberal bir ekonomiye geçişi, Avrupa ile olan ticaretin hızla gelişmesi ve şehirleşme, Balkanlar'da yerli bir tüccar sınıfını ortaya çıkardı. Bu durum, söz konusu bölgede etnik kimliklerin belirgin bir hale gelmesini sağlayan önemli etkenlerden birini teşkil etmiştir (Saatçi 2009: 23). Osmanlı tebaası olup ticaretle hızla zenginleşen Hristiyan tüccar gruplarının ortaya çıkması; Aydınlanma Çağı Avrupa'sının ve daha sonra Fransız İhtilali'nin etkisi altında, ulus devlet düşüncesinin ve etnik bilincin oluşmasında rol oynayan bir aydın sınıfının da doğmasını sağlamıştır (İnalcık 2005: 2840; Karpat 2004: 78). XIX. yüzyıla kadar kendilerini dinî kimlikleriyle tanımlayan halklar (Müslüman, Hristiyan, Yahudi), bu yüzyıldan itibaren yine dinî bir mücadele alanı olan müstakil kiliselerin kurulması için verilen mücadele sırasında etnik ve dilsel kimliklerini ön plana çıkarmaya başladılar. Helenleştirme politikalarına karşı Bulgarların, Sırpların ve diğer etnik unsurların kendi kiliselerini kurma yolundaki azimleri, Balkanlarda millî kimliklerin ortaya çıkışını derinden etkileyen bir başka sebep oldu. Karpat'a göre, Balkan milletlerinin fikri uyanışında etken olan başka bir amil de göç olgusudur. $\mathrm{Bu}$ anlamda II. Viyana Kuşatması'ndan sonra Balkan topraklarında yaşanan savaşlar, Osmanlı tebaası olan Sırpların, Bulgarların, Rumların ve diğer etnik unsurların yaşadıkları yerlerden göç etmelerine sebep olmuştur. Kuşkusuz bu göçlerin Balkan milletlerinin geleceği üzerinde önemli toplumsal, siyasal ve kültürel etkileri oldu (Karpat 2004: 78).

Rusya'nın büyük bir güç olarak ortaya çıkması ve Balkanlarda Pan-Slav politikalar takip etmesi, Balkan milletlerinin kimlikleri üzerinde belirleyici rol oynayan diğer bir husustur (Yetim 2011: 290-291). Özellikle 1768-1774 y1lları arasında devam eden ve Rusların Osmanlı'ya galebe çalmasıyla sonuçlanan savaşlar, Balkan coğrafyasında yaşayan halkların tarihini de etkileyen bir durum yarattı. İstanbul'un fethiyle Ortodoksların hamisi konumuna gelen Osmanlı Devleti'ne karşı, Rusya 1774 Küçük Kaynarca Antlaşma'sıyla aynı milletin hamisi olduğunu ileri sürdü (Karpat 2002: 20). Bu politik iddia kuşkusuz Balkan milletlerinin millî devletlerini kurmalarında önemli bir rol oynayacaktı.

Balkanlarda mevcut olan kültürel milliyetçilik, Fransız İhtilali'nin ortaya çıkarmış olduğu fikrî ve siyasî telakki ile farklı bir mecraya doğru evirildi. Osmanlı devlet adamları, 1789'da Fransa'da ihtilal patlak verdiğinde yakın gelecekte dünyayı değiştirecek bu olaya karşı kayıtsız kalmışlardı. Hatta denilebilir ki Avrupa'nın içlerinde yaşanan bu karmaşadan dolayı memnuniyet duymuşlardı (Lewis 1984: 66). Osmanlı devlet adamlarının Fransız İhtilali karşısında takınmış oldukları kayıtsız tavra karşın, ihtilalin getirmiş olduğu fikirler kısa sürede devletin Hristiyan tebaasını etkileyecektir.

İhtilalinden sonra erken sayılabilecek bir dönemde başlayan Sirp isyanı (1804) ve bu isyan neticesinde Sirpların elde etmiş olduğu haklar (1815), (Bkz. Sertoğlu 2011: 28582865) Osmanlı Devleti için ulusçuluk temelli daha büyük problemlere kap1 aralar nitelikte idi. 1821'de başlayan ve Yunanlıların bağımsızlığı ile neticelenen (1829) Mora'daki Rum isyanı ise diğer Balkan milletleri için adeta bir işaret fişeğiydi (Sezer 2002: 91-92). Büyük devletlerin Rum isyanına vermiş olduğu destek (Bkz. Bayrak 2002: 71-86. Bostan 2006: 441-443), Osmanlı Devleti'nin diğer Hristiyan tebaasının da benzer politikalar takip etmesine sebep olmuştur. Ayrıca Osmanlı Devleti'nden ayrılan veya özerklik elde eden gayrimüslim tebaanın gerek sınırlarını genişletme gerekse elde etmiş oldukları hakları artırma isteği ve bunların açtıkları gaileler XIX. asırda uluslararası arenada devleti sürekli zor durumda bıraktı.

Osmanlı diplomatları Tanzimat döneminde etnik kimliğe dayalı meydana gelen birçok ayrılıkçı isyanın üstesinden gelmek için yoğun çaba harcadı. Girit Meselesi, Sırp, Karadağ, Bosna-Hersek İsyanları Romenlerin ulusal birliklerini oluşturma süreci, Bulgar problemi bahsi geçen dönemde cereyan etti. 1877-1878'de meydana gelen ve akabinde Ayestefanos ve Berlin Antlaşmalarının imzalanmasına sebep olan Osmanlı-Rus Harbi, Balkan milletlerinden Sırbistan, Karadağ ve Romanya'nın bağımsız birer devlet olarak ortaya çıkmasına sebep oldu. Bulgaristan ise neredeyse bağımsız sayılabilecek özerk bir yapıya kavuşturuldu (Armaoğlu 2006: 526-527). Sultan II. Abdülhamid'in tahta çıkışının ilk yıllarında cereyan eden bu hadiseler, onun daha sonraki Balkan politikasını derinden etkiledi. Makalede, Sultan II. Abdülhamid'in Balkan siyaseti genel hatlarıyla değerlendirilmekle birlikte, temel olarak 1884'te Osmanlı Devleti'nin hizmetine giren ve Osmanlı ordusunun gerek yapısal olarak gerekse teçhizat olarak modernleştirilmesine büyük katkılar sunan Goltz Paşa'nın Balkan Meselesi hakkında düşüncelerine yer verilecektir.

\section{Sultan II. Abdülhamid ve Balkanlar}

1878 'de imzalanan Berlin Antlaşması, Osmanlı Devleti için Balkan coğrafyasına veda anlamı da taşıyordu. Her ne kadar Bulgaristan özerk olarak Osmanlı egemenliğinde kalmaya devam etmiş olsa da gerçekte, tıpkı Yunanistan, Sırbistan, Romanya ve Karadağ gibi müstakil bir devlet haline gelmişti. Antlaşmanın sonucunda Osmanlılar sadece Makedonya, Trakya, Teselya ve Arnavutluk'u kapsayan topraklar1 elinde tutabildi (Gencer 1992: 516-517). Kuşkusuz bu elde kalan topraklar üzerinde de mutlak bir egemenlik yoktu. Savaşın nihayete ermesi, devlet için sorunların bittiği anlamına da gelmiyordu. Özellikle Balkan coğrafyası tam anlamıyla kaynayan bir kazan gibiydi. Uzun süre Osmanlı Devleti'ne tabi olarak yaşamış olan balkanların yeni ulus devletleri için bağımsızlıklarını elde etmek yeterli bir sonuç değildi. Hepsi de kadim geçmişlerine vurgu yaparak gerek birbirlerinin elindeki ve gerekse Osmanlı sınırları içerisinde kalmış olan topraklar üzerinde hak talep ediyorlardı (Shaw-Shaw 2006: 243). Örneğin Makedonya üzerinde birçok millet hak iddia ediyor ve bu amaçla kurdukları dernekler ve örgütler vasıtasıyla hem birbirlerine hem de Osmanlı Devleti'ne karşı mücadele ediyorlardı (Bkz. Adanır 2001: 108-110,232-250). Söz konusu antlaşma bu anlamda balkanlarda barış ortamını sağlayamamıştı. Bir başka örnek ise Doğu Rumeli meselesiyle ilgilidir. Bulgaristan, Berlin Antlaşması ile Osmanlı Devleti'nin egemenliğine bazı özel şartlarla bırakılmış olan Doğu Rumeli'yi topraklarına katmak için faaliyetlerini hızlandırdı (BOA. HR. SYS. 358/4, A. MTZ. (04), 20/16). Bulgar Prensliği ile Doğu Rumeli'nin birleşmesi (18 Eylül 1885) (Adanır 2001: 113), antlaşmanın hükümlerine açık bir şekilde aykırı olsa da Sultan II. Abdülhamid geliri azalmış ve sürekli olarak problem teşkil eden bu vilayetin Bulgaristan ile birleşmesini Bulgar-Rus birlikteliğini 
baltalamak amaciyla kabul etti (Shaw-Shaw 2006: 247). Balkan milletlerinin bağımsızlığı Osmanlı Devleti'ne sadık kalmış olan son toprak parçalarından Arnavutluk'ta da milliyetçi örgütlenmelerin önünü açt1. 1 Haziran 1878 'de Prizren'de kurulan Arnavutluk Birliği toprak bütünlüğü tanınmış ve özerk yapıya sahip Arnavutluk'un kurulması için diğer Slav unsurlara karşı mücadeleye başladı (Kılıç, 2006: 260). Ayrıca Berlin Antlaşma'sından sonra örgüt Osmanlı yönetimini, topraklarını Slavlara peşkeş çekmekle suçladı (Hacısalihoğlu 2018: 108). Bu düşünce Arnavutlar nezdinde de Osmanlı Devleti'yle bir gelecek tasavvurunun zayıfladığını göstermesi bakımından önemlidir (Çatma, 2019: 54). Gelişen bazı hadiseler karşısında Meclis-i Hass'da sert tedbirlerin alınması gündeme gelmiş, ancak Sultan Abdülhamid, devlete sadık olan bu halkın tutumunun altında yatan sebeplerin olduğu/olabileceği gerekçesiyle bu düşünceye karşı çıkmıştır. Hatıratında hürriyete alışkın bu millete karşı hüsnü niyetle hareket edilmesi gerektiğini belirtmiştir (Sultan Abdülhamid 2010: 69-70).

Esasında Balkanlardaki milletler tek tek düşünüldüğünde Osmanlı Devleti'nin toprakları üzerinde hepsinin birtakım emelleri söz konusuydu. Yunanistan bağımsızlı̆̆ını elde ettikten sonra Osmanlı Devleti aleyhine sınırlarını genişletmek için her firsatı değerlendirmeye çalışmıştır. Batılılarında desteği ile zaman zaman Girit'te isyanlar çıkmasına sebep olan Yunanistan, 1881'de büyük güçlerce ödüllendirilmiş ve Teselya bölgesi Yunan topraklarına katılmıştır. Ancak bu Yunanistan ile problemlerin bittiği anlamına gelmiyordu. ${ }^{1}$ Nitekim 1897 Türk-Yunan Savaşı problemlerin sıcak çatışmaya dönüştüğü tarih olarak kayıtlara geçti.

1878 Berlin Antlaşması'ndan sonra oluşan yeni statüko ve batılı güçlerin desteğini arkasına almış olan Balkan milletleri karşısında Sultan II. Abdülhamid devletin toprak bütünlüğünü korumak amacıyla tedbirler almaya çalışmıştır. Geleneksel olarak İngiltere veya Fransa'ya dayanan Osmanlı diplomasisi 1877-1878 Savaşı boyunca ve Ayastefanos ile Berlin Antlaşmalarının görüşmeleri sırasında karşılaştığ durumdan ötürü (BOA. Y. EE. d. 1016), yeni bir müttefik arayışına girmek durumunda kalmış ve Almanya ile ilişkiler hızlı bir şekilde geliştirilmiştir. İki devlet arasında gelişen ilişkiler, dış politikada Osmanlı Devleti'nin yalnızlığını giderecek bir adım olarak düşünülmüştür. Nitekim Almanya ile bu dönemde başlayan sıkı ilişkileri, iki devletin I. Dünya Savaşına aynı cephede katılmasına kadar varmıştır (Bkz. Kara 2013).

Sultan II. Abdülhamid ve dönemin Osmanlı devlet adamları Avrupalı devletlerin kendilerine karşı örtülü bir haçlı seferi yürüttüğünü düşünüyordu. Özellikle İngiliz Başvekil Glodstone'un Papa II. Pie'nin izinden gittiğini belirten Sultan, Bulgarların ve Ermenilerin yaptığı katliamları görmeyen Batılıların, asayişi sağlamak için Osmanlı Devleti'nin giriştiği harekata karşı çıkmasını bu çerçevede değerlendiriyordu. Ayrıca Sultan İspanyolların, İngilizlerin, Rusların ve Fransızların işgal ettikleri bölgelerdeki halklara karşı giriştikleri hareketlerin katliam boyutuna varmasına karşı ses çıkarmayan batılı kamuoyunun, Türk idaresinin

\footnotetext{
1 Örneğin Osmanlı hükümetinin resmi dilin Türkçe olmasına dönük iradesine ilk karşı çıkan devlet Yunanistan olmuştur. Bkz. Fahri Yetim, “Osmanlı İmparatorluğu'nun Dağılma Döneminde Balkan Milliyetçiliği ve Büyük Güçler”, s. 293.

2 Gladston'un Türklere bakış açısın Avrupa'dan tamamen kovulmaları siyasetine dayanıyordu. Lord Salisbory Sırbistan elçilerinden biriyle yaptığı
}

isyanlar karşısında almış olduğu tedbirleri sorgulanmasını tamamen haçlı zihniyetiyle bağlantılı görüyordu (Sultan Abdülhamid 2010: 99, 141-142). ${ }^{2}$ Avrupalı büyük güçlerin Arnavutluk'ta, Makedonya'da, Doğu Rumeli'de sadece Hristiyan unsurları düşünerek hareket etmeleri, bu yolda isteklerde bulunmaları, Osmanlı devlet adamları nezdinde, devletin topraklarını parçalamaya dönük haçlı düşüncesinin tatbiki olarak görülüyordu. (BOA. Y. PRK. TKM., 47/18; Ademi 2018: 183).

$\mathrm{Bu}$ gerçeklerden hareketle, Sultan II. Abdülhamid, büyük devletler karşısında uygulamış olduğu denge politikasını Balkan milletlerine karşı da kullanmıştır. Sultan, yerel hanedanlarla dostluk ilişkileri kurarak ve Balkan milletleri arasındaki problemlerden faydalanarak Osmanlı Devleti'nin balkanlardaki varlığını devam ettirmeye çalışmıştır. Bu bağlamda Karadağ Prensi ile yakın ilişkiler geliştirmiş ve kendisini sık sık taltif etmiştir. Zor zamanlarında Karadağ'a maddi yardımda bulunan Sultan II. Abdülhamid, Emirgan yalısını Prens'e hediye ederek kendisinin Sırbistan hakkındaki düşüncelerinden istifade etmeye çalışmıştır (Özcan 2012: 120-121; Kazel 2019: 22).

Bulgarların yakından takip edilmesi gerektiğini düşünen Sultan II. Abdülhamid, bu konuya özel bir hassasiyet göstermiştir. Örneğin Prens Ferdinand'in her sene tatilini geçirdiği Rilo Manastırı'nın aynı zamanda asi Bulgarların karargâh olarak kullandığını ve Bulgaristan yönetiminin asilere doğrudan yardımda bulunduğunu hatıratında açık bir şekilde belirtmiştir (Sultan Abdülhamid 2010: 77). Bu olaydan da anlaşılacağ1 üzere Sultan, istihbarat ağ1 vasıtasıyla özellikle Osmanlı Devleti için tehlike olarak gördüğü Bulgarların ne yapıp ettiklerini yakından takip etmiştir (Ademi 2018: 186-187; Sultan Abdülhamid 2010: 110-111).

Bahsi geçen dönemde Osmanlı Devleti'nin Balkan politikasının temeli, Balkan milletlerinin bir araya gelmesini önlemeye dönüktür (Kuran 1994: 141; Erdoğdu 1999: 167167; Gümüş 2019: 253). Bu bakımdan, Sultan II. Abdülhamid'in Balkan siyasetinin temeli, Balkan devletleri arasındaki problemlere dayalıdır denilebilir. Sırp ve Yunanlıların ortak menfaatlerinin bulunması ve bu açıdan Bulgarlara karşı bir cephenin oluşmasını önemseyen Sultan, Bulgarların siyasî hırslarının dizginlenmesi için bu birlikteliği hayırlı iş olarak görmüştür. Nitekim Balkanlardaki Bulgarlaştırma siyasetine karşı Helenizm'i tabii müttefik olarak desteklemiştir. Sultan II. Abdülhamid hatıratında bu durumu şöyle izah etmiştir:

“Atina sefirimiz Rlfat Bey, Yunanistan'la münasebetimizin iyi bir şekilde devam etmesi için bütün gayretini sarf etmelidir. Yunanistan 'la harp etmeye mecbur olmayı katiyen istemiyorum. Aramızın bozulmaması iki memleket için de lüzumludur.

Yunanlılar, Bulgar-Slav istilasına karşı koyabilmek için yardımımıza muhtaçtırlar. Aynı şekilde bizde Bulgarlarla mücadele edebilmek için, eskiden beri düşmanları olan

bir görüşme sırasında Gladston'un bir Balkan Birliği siyasetinden bahsederek şunu ifade etmiştir: "Biz İngilizler için tek doğal ve mantıklı politika varsa, o da Türklerin pılı pırtılarlyla birlikte Avrupa'dan kovmak..." dır. Bonyar Waylet-Ernst Jackh, Imparatorluk Stratejileri ve Ortadoğu, (Çev. Vedat Atülla), Chiviyazıları Yayınevi, İstanbul 2004, s. 266. 
Yunanlılardan daha iyi yardımcl bulamayı." (Sultan Abdülhamid 2010: 116-112) ${ }^{3}$

Sultan II. Abdülhamid'in Balkanlarda uygulamış olduğu politika durağan bir seyir izlememiştir. Zamanın şartlarına göre Bulgarlarla ittifak yapmak da Osmanlı siyasetinin gündemine girmiştir. Nitekim Prens Ferdinand bağlılığını sunmak üzere İstanbul'a geldiğinde bu minvalde görüşmeler de olmuştur. Hatta Prens Sofya'ya geri döndükten sonra bu durumu destekleyici nitelikte Bulgar Başvekil Stoilov "Bizim ruhumuz İstanbul'dadır." mealinde bir konuşmada yapmıştır (Salih Münir Paşa 2015: 373).

Sultan II. Abdülhamid devri siyasî tutum analiz edildiğinde görülecektir ki, Slav düşüncesi ile Helen düşüncesinin bir dengede tutulması ve bunlardan yararlanılması öncelikli düşünce olmuştur. Nitekim Osmanlı devlet adamları Bulgarların Slavlaştırma politikasına karşı Helen düşüncesini doğal bir müttefik olarak görmüşler, Yunanistan'ın Balkanlarda gütmüş olduğu Helenleștirme politikasını da benzer bir siyasî araç olarak değerlendirmişlerdir. Helenleştirme politikası bazı Rum olmayan Hristiyanlar içinde karşılık bulmuş olsa da Slav asıllı Bulgar, Sırp ve Ulah gibi milletlerin ve yöneticilerinin muhalefetiyle karşılaşmıştır. Bu anlamda en sert reaksiyonu Bulgarlar göstermiştir (Karpat 2006: 266; Ortaylı 1985: 1029). Bu durum Osmanlı Devleti'nin ve Sultan'1n Balkanlarda kurmak istediği siyasetle de örtüşüyordu. Abdülhamid bu durumu hatıratında şöyle dile getirmektedir:

"Bizim Avrupa'daki kudretimizin, Balkan devletlerinin birbirleriyle anlaşmamalarl üzerine kurulduğu doğrudur. Sirplarla Bulgarlar birbirlerini sevmezler; Bulgarlar Romenlerden nefret ederler; Romenler, Bulgarlar ve Yunanlılar kendi aralarinda birbirlerine ölesiye düşmandırlar. Bulgarlara göre Makedonya'da kendi milletleri hakimdir. Yunanlllar ise, Makedonya'daki Yunanlıların zorla Bulgarlaştırıldıklarını iddia ederler. Kiliseler arasında 1870 senesinde meydana çıkan ihtilaf, Bulgarlarla Yunanlıları tamamıyla ayırmıştır." (Sultan Abdülhamid, 2010: 125).

Sultan II. Abdülhamid özellikle Balkan halkları arsındaki kiliseler problemini önemli siyasî bir enstrüman olarak görmüş ve bu enstrümanı mahirane bir şekilde kullanmıştır (Ortayl1 2017a: 23). Kendisi, Rum-Ortodoks Kilisesi'nin ayrılmasını Babıâli'nin hatası olduğunu, Bulgar Kilisesi'ne Eksarklık vermenin de Abdülaziz'in hatası olduğunu düşünüyordu. (Ortayl1 2017b: 30-31; Engin 2011: 35, Sultan Abdülhamid 2010: 126). Bu bağlamda, I. Balkan Savaşı'nın İttihat ve Terakki'nin çıkarmış olduğu Kiliseler ve Mektepler Kanunu'ndan sonra çıkması tesadüfi olmasa gerekir (Bkz. Küçük 1992: 23-25; Kerimoğlu 2007: 3-25).

\footnotetext{
${ }^{3}$ Sultan II. Abdülhamid büyük devletleri çıkarabilecekleri problemlere göre kategorize edip ona göre bir politika geliștirmeye çalıșmakla birlikte, büyük devletlerin ihtiraslarına set çekecek asıl önemli hususun Müslümanlar arasında bir ittihat meydana getirmekten geçtiğini düșünüyordu. $\mathrm{Bu}$ bağlamda İngiltere, Fransa, Almanya, Rusya, Avusturya, Almanya, İtalya ve Yunanistan'ın siyasî emellerine ayrı ayrı değinen Sultan, bu devletlerin amaçlarının ne olduğunu muhtıralarında açıklamıștır. Bkz. Sultan II. Abdülhamid Han, Devlet ve Memleket Görüşlerim, (Haz. A. Atilla Çetin), Cilt I, Çamlıca, İstanbul 2011, s. 30-35. Sultan II. Abdülhamid Han, Devlet ve Memleket Görüşlerim, (Haz. A. Atilla Çetin), Cilt II, Çamlıca, İstanbul 2011, s. 25-28.

${ }^{4}$ Colmar Freiherr Von Der Goltz, 12 Ağustos 1843 'te Doğu Prusya'da Labiau kasabası yakınlarında Bilkenfeld'de doğmuştur. 1864'te Berlin
}

\section{Goltz Paşa'nın Osmanlı Devleti’nin Balkan Problemine Bakışı}

Sultan II. Abdülhamid döneminde devletin Balkan politikasını etkileyen birçok parametre vardı. Osmanlı devlet adamlarının bu dönemde bir taraftan Balkanların küçük ulus devletlerini dizginleyecek politikalar geliştirmesi, diğer taraftan da büyük devletlerin Balkanlar özelinde devletin temel dinamiklerini sarsacak isteklerini idare etmesi gerekiyordu. 1877-78 savaşından sonra Osmanlı Devleti hem büyük toprak parçası hem de büyük bir nüfus kaybetti. Balkanlarda savaş öncesine oranla elde çok az toprak kalmış olmasına rağmen, bu topraklarda da problemler bitmek bilmiyordu. Bütün iyi niyetli çalışmalar, büyük güçler ve Balkan devletleri tarafindan görmezden geliniyor ve baltalaniyordu.

Balkan problemiyle ilgili gerek Osmanlı devlet adamları tarafından gerekse büyük devletlerin diplomatları tarafından birçok düşünce serdedilmiştir. Konuya kendi çıkarları açısından bakan Avrupalılar, hazırlamış oldukları birçok projede Balkan milletlerini -Hristiyan tebaay1önceliyorlardı. Osmanlı devlet adamları ise devletin parçalanmaması için çareler arıyordu. Konuyla ilgili fikirlerini paylaşan önemli kişilerden birisi de uzun dönem Osmanlı hizmetinde olan Goltz Paşa'dır. ${ }^{4}$ Paşa Sultan II. Abdülhamid dönemi askerî modernleşmenin önemli aktörü olarak, özellikle Alman tarzı bir subay heyetinin yetişmesi ve Türk-Alman ittifakının kökleşmesinde önemli bir rol oynamıştır. $\mathrm{Bu}$ bakımdan Osmanlı Devleti'nin Balkan siyaseti hakkında serdettiği düşünceler önemlidir. Yazmış olduğu uzun makalesinde Goltz Paşa, dönemin Osmanlı siyasetini ve Balkan devletlerinin durumunu şu şekilde izah etmektedir:

"Sulh ve âsâyişin te'mîn-i muhâfaza ve idâmesi için her türlü fedâkârlık ihtiyâr olunduğu hâlde hiçbir fâ'ide istihsâl olunamayan ve vesâ'it-i insâniyet-kârâne ile de halli mümkiün olamayan mesâ'il-i siyâsiye var ise o da Balkan Mes'elesi'dir. El-Yevm şekl-i hâzırı iktisâb eden işbu mes'ele ortalık sulh ve âsâyiş-i tâmm içinde bulunduğu ve meydânda hiçbir sebeb-i zâhiri görülmediği bir ânda Rûmeli-i Şarkî'nin bağteten taht-l idâre-i Devlet-i Aliyye'den infikâk ettirildiğ $i$ fì 18 Eylül 1885 tarihinde ser-zede-i zuhûr olan Filibe Vak'asıly ibtidâr eylemiştir." (BOA. Y. PRK. MYD., 26/97: 1).

Sultan II. Abdülhamid döneminde Balkanlardaki durum tam da Goltz Paşa'nın belirttiği şekliyle, devletin iyi niyet ve fedakarlıklarına rağmen problemlerin çözümünde bir türlü istenen netice elde edilememiştir. Bu, kuşkusuz Balkan milletlerinin Osmanlı Devleti'ne bakışıyla doğrudan ilintilidir. Tanzimat dönemi aydınları ve devlet adamlarının Osmanlıcılık fikri etrafından Müslim-gayrimüslim bütün

Harp Akademisi'ne giren Goltz, eğitimini tamamladıktan sonra Piyade Teğmen olarak mezun olmuştur (26 Nisan 1861). Osmanll Devleti'nin askerî okullarda ĕgitimin iyileştirilmesi için Almanya'ya başvurması üzerine, Alman Genel Kurmayl'nın önerisi ile 18 Haziran 1883 'te Istanbul'a gelmiştir. 1883'ten 1895'e kadar Osmanlı ordusunun eğitilmesinde danışmanlık yapan Prusyalı General, Osmanlı subaylarının, Prusya askerî zihniyetine uygun yetistirilmesi ve Alman silah sanayinin Türkiye'de tekel konumuna gelmesinde büyük rol oynamıştır. Ayrıntılı bilgi için bkz. Hidayet Kara, Sultan II. Abdülhamid Dönemi Osmanlı Kara Ordusu (1876-198), Atatürk Üniversitesi Sosyal Bilimler Enstitüsü, (Yayınlanmamış Doktora Tezi), Erzurum 2013. 
tebaayı bir arada tutmaya yönelik çabaları, 1877-78 harbiyle büyük bir darbe almıştır. Tanzimat dönemi boyunca Balkan coğrafyasının birçok yerinde meydana gelen isyanlar ve bu isyanların rengi ortak yaşam konusunda Balkan milletlerinin pek de hevesli olmadığını göstermiştir. Nitekim ilk Meclis-i Meb'ûsan'da da belirgin olmasa da gayrimüslim milletvekillerinin bazılarında ulusçu düşüncelerin hâkim olduğu görülmüştür (Ortaylı 2008: 255). Goltz Paşa, balkanlardaki siyasî düşün açısından iyi niyetle hareketin çok da işe yaramayacağı görüşündedir. Paşa, Filibe vakıasını örnek vererek, devletin bu olay karşısında zecrî tedbirler alması gerektiğini, “... zamânda cür'et-kârâne hareket ekseriyâ kâr-l âkildir" diyerek ifade etmektedir. Keza Osmanlı Devleti'ne dost olan yönetimlerinde kendilerine bu yolda tavsiyelerde bulunduğunu belirtmektedir. $\mathrm{Bu}$ tavır aslında devlet için hayati derecede önem arz etmektedir. Çünkü Paşa'ya göre eğer gerekli tedbirler alınmazsa Ayastefanos'un kurmuş olduğu büyük Bulgaristan yeniden gündeme getirilecektir. ${ }^{5}$ Kuşkusuz bahsi geçen antlaşmanın öngörmüş olduğu şekilde bir Bulgar devletinin ortaya çıkması Osmanlı Devleti'nin bütün Balkan topraklarının elden çıkması anlamına gelecekti.

Goltz Paşa'nın sert önlemler alınması görüşüne karşı, Sultan II. Abdülhamid, 93 Harbi'nden sonra yeni bir savaştan özellikle kaçınmak için Balkanlarda çıkan problemler karşısında doğrudan askerî tedbirler yerine farklı siyasetler izlemiştir. Problemler karışışında kimi zaman idarî tedbirler alan Sultan, (BOA, Y. PRK. BŞK., 64/53) kimi zaman da problem çıkaranlara nasihatçiler gönderme yolunu seçmiştir. Örneğin 13 Cemaziyelevvel 1319 tarihli bir belgede eşkıyaya iltihak eden Bulgarların köylerine geri dönemlerini ve ellerindeki silahları devlete teslim etmelerini sağlamak için nasihatçiler gönderilmişti. Dağlı eşkıyanın yanında bulunan köylüleri ikna etmek için heyetler gitmiş ise de belgenin devamından anlaşıldığı kadarıyla istenilen netice tam olarak hasıl olmamıştır (BOA. TRF. I. A., 12/1189; Bkz. BOA. İ. HUS., 108/28). ${ }^{6}$ Ancak güç kullanmanın hangi sonuçlara gebe olacağı, dönemin siyasî atmosferi düşünüldüğünde tahmini hiç de zor konu değildir. Esasında Osmanlı Devleti 1876'daki Bulgar isyanı sırasında Goltz Paşa'nın belirttiği şekilde bir politika izlemişti. Hatta Ferik Fazıl Paşa'nın orantısız güç kullanması, bazen ele geçen Bulgarların muhakeme edilmeksizin asılması (Mahmut Celaleddin Paşa 1983: 124) büyük devletler nezdinde ciddi tepkiyle karşılanmış ve Müslümanların katliam yaptığı iddiası ortaya atılmıştır (Bkz. Bağçeci 2014: 211-235). Kuşkusuz büyük devletlerin bu iddiaları ve tutumlarının asıl hedefi Osmanlı Devleti üzerindeki tazyiki artırmaktır. Her ne kadar Sultan II. Abdülhamid'in genel tavrı mümkün mertebe problemleri siyasî yolla çözmek olsa da toprakların muhafazası için savaşa girmekten de çekinmemiştir. Nitekim

\footnotetext{
5 "Erbâb-1 vukûftan birisi vak'a-i mezkûre üzerine eğer Bâb-1 Âlî Rûmeli-i Şarkî hâdisesine bilâ-i'tirâz sükût edecek olursa Ayastefanos Musâlahası mes'elesi tekrâr meydâna konacak demiştir. Ma'lûm olduğu üzere ayastefanos Musâlahası Makedonya'nın kâffesiyle Kavala civârında Adalar Denizi'ne müntehî ve Yanya Vilâyetiyle Arnavudluk ve Tesalya Kıt'ası ve Edirne Vilâyeti'nin bir kısmı hâric olarak Balkan Şibh-i Cezîresi'nin aksâm1 mütebâkiyesini hâvî bir büyük Bulgaristan vücûda getirmiș idi. İșbu vüs'ati ibkâ edilmiş olaydı emâretin civâr-1 hükûmetlere nisbetle pek kuvvetli bulunacağı der-kâr idi. Berlin Kongresi şu parlak istikbâl hayâlâtını bozup Bulgaristan Emâreti'ni Balkan silsilesinin şimâl kısmı ve şimdiki makarr-1 emâreti olan Sofya ile tahdîd ederek hükûmât-1 sâ'ire-i Hıristiyâniye ile başlamakta olan reakbete bir sedd-i mâni‘ teşkîline çalışmıştır.” BOA, Y.PRK. MYD., 26/97, s. 1.
}

1897 Yunan Harbi bu durumu kanitlar niteliktedir (Jorga 2009: 502).

Goltz Paşa'ya göre, Osmanlı Devleti'nin batılı devletlerinde baskısıyla tavizkar bir politika izlemesi, Balkanlarda çıkan problemler karşısında askerî tedbirler yerine farklı siyasî enstrümanlar kullanması bölgede suların durulmasına yardımcı olmamıştır. Nitekim Paşa konuyla ilgili şu düşüncededir:

"Vak'a-i mezkûreden beri yirmi üç sene mürûr eylediği hâlde bu müddet zarfinda Balkan Şibh-i Cezîresi'nde dâ'imî bir âsâyiş-i tâmm vücûda gelmemiştir. Bazı zâhirî sükûnlarda sâlifü'z-zikr tavsiyemin sevâb? olduğuna şübhe eder idim. Fakat bugün artık kat 'iyen emîn oldum." (BOA. Y.PRK. MYD., 26/97, s. 1-2).

Böylece Paşa, Balkanlar konusunda daha önce ileri sürmüş olduğu tedbirler konusunda haklı olduğunu ifade etmiştir. Çünkü Balkan milletleri ve özellikle de Bulgarlar, bütün iyi niyetlere karşın Osmanlı Devleti aleyhine olan bütün hareketlerin içinde yer almaktan geri durmamışlardır. Ayrıca kendi aralarında derin problemleri olmalarına rağmen Makedonya örneğinde olduğu gibi, bu problemleri bir tarafa bırakarak birlikte hareket ettikleri dönemler de olmuştur. 23 Ramazan 1314 tarihli bir belgeden anlaşıldığı kadarıyla Belgrad, Bükreş ve Atina sefaretlerinden bu minvalde istihbarat alınmıştır (Y. PRK.HR. 23/53; Bkz. Y. PRK. HR. 23/55). Sultan II. Abdülhamid'in muhtıralarından anlaşıldığına göre, Bulgaristan ile Karadağ arasındaki ittifak bilinen bir durumdur. Bulgar Prensi dahi bu durumdan açıktan açığa bahsetmektedir (Sultan Abdülhamid 2011a: 86-87). Bu durum gösteriyor ki Balkan milletleri Osmanlı toprakları üzerinde kendi menfaatleri doğrultusunda ittifak çabaları içerisine girebilmektedir. ${ }^{7}$ Sultan II. Abdülhamid bu durumun farkında olduğunu, muhtıralarında açık bir şekilde ortaya koymaktadır. Nitekim Sultan, her devletin süreklilik arz eden ve hükümetlerin gelip gitmesiyle değişmeyen politikalarının olduğunu, Osmanlı Devleti'nin de bu minvalde devletin devamlılı̆̆ını sağlayacak genel geçer politikalar üretmesi gerektiğini ifade etmiştir. $\mathrm{Bu}$ düşünceden hareketle Sultan, Osmanlı Devleti ile çeşitli şekillerde ilişki içinde olan ya da olması beklenen devletlerin genel eğilimlerini ve Osmanlı coğrafyası üzerindeki emmelerini tespit etmiştir. $\mathrm{Bu}$ bağlamda Padişah'ın Yunanistan'ın siyasî tutumuna yönelik tespitleri önemlidir. Sultan II. Abdülhamid

"Yunan devleti de tevsi-i memleketle tezyîd-i kuvvvet ve kudret için Yanya ve Manastır ve Selanik vilayetlerini hatta muktedir olabilirse ise İstanbul'u zapt etmek arzusunda ise de karşusunda Avusturya gibi kuvvetli bir rakip görüldüğü cihetle daha ilerisinden kat'ı ümid ile evvel be-evvel Yanya ve Serfice taraflarinı ve def'a-i saniyede Bahr-i Sefid'de

\footnotetext{
${ }^{6}$ Sultan II. Abdülhamid döneminde yürütülen nasihat siyaseti çerçevesinde komisyonlar olușturulmuştur. Bu komisyonlarda hem Müslüman hem de Hristiyan üyeler yer almıştır. "Eş̧kıya hadisesi üzerine karyelerini terk ile dağlara çekilen ve eşklyaya iltihak etmiş olan Bulgar ahalisinden henüz avdet etmiş olanların hemen iadeleri için mutasarrif ve kaza kaymakamlarının ve meclis idare azasından Islam ve Hristiyan birkaç kişi ile mevcut ise rüesay ruhaniye dahi refakatlerine alarak...” BOA., TFR. I. AS., 7/663.

7 Osmanlı devlet adamlarının Balkan savaşlarından önceki en büyük yanılgıları Balkan uluslarının bir araya gelmeyeceği tezidir. Makedonya olayında görüleceği üzere esasında Osmanlı Devleti’ne karşı birlikte hareket etmeye dönük teșebbüslerin tarihi daha eskidir.
} 
bulunan Cezâyir-i şâhâneyi ele geçirmek mesleğini tutmuştur." (Sultan Abdülhamid 2011b: 28).

diyerek Yunanistan'ın nihai amacını ortaya koymuştur. Ayrıca Sultan, her ne kadar Goltz Paşa'nın önerdiği şekliyle silahlı gücü ön plana çıkarmasa da -ki daha önce değinildiği gibi Osmanlı Devleti'nin askerî güç kullanımı için ne devletin kendi durumu ne de uluslararası siyaset uygun değildir-, Hristiyan milletler karşısında siyasî enstrümanlarını çoğaltmaya çalışmıştır. $\mathrm{Bu}$ bağlamda Müslümanların birlikte hareket etmesi gerektiğine inan Sultan II. Abdülhamid, İran ile iyi ilişkiler kurulmasına çalışmış ve bütün Müslümanların ortak hareket etme kabiliyetine ulaşmasını prensipleri arasına koymuştur (Sultan Abdülhamid 2011a: 32-35). Şunu da ifade etmek gerekir ki bu dönemde Balkanlarda sükûnetin sağlanması, Osmanlıların gütmüş olduğu politikalara bağlı değildir. Problem sadece, probleme doğrudan taraf olan devletlerin ikili ilişkilerle çözebileceği bir sorun da değildir. Balkan problemi, probleme taraf olan devletlerle birlikte büyük güçlerinde memnun edilmesine bağlı çok daha çetrefilli bir sorundur.

Goltz Paşa'ya göre Osmanlı Devleti’nin Balkanlarda sükûneti sağlamaya ve refahı artırmaya yönelik çabaları, Bulgar, Sırp ve Yunan devletlerinin desteklediği eşkıyalar tarafından sekteye uğratılmaktadır. Eşkıya faaliyetleri ve ayrılıkçı hareketler, terakki ve ümranı için ne gerekli olan süreye firsat tanımış ne de huzur ve rahat bırakmışlardır. (BOA, Y.PRK. MYD., 26/97, Bkz. Enver Paşa, 2015: 25 30). $\mathrm{Bu}$ durum esasında bahsi geçen milletlerin Osmanlı Devleti ile olan ortak gelecek tasavvurunun yok olduğunu göstermektedir. Talat Paşa anılarında bu minvalde şu önemli tespiti yapmaktadır: "Bir yandan Yunanlılar, bu hükümetin sürmesini devletin kesin olan çökmesiyle sonuçlanacağını anlıyor ve kendilerini de, özellikle Rumeli'de onun mirasçısı olarak görüyorlar. "(Mehmet Talat Paşa 2013: 16). Paşa'nın, Yunanlı dostu Avukat Marko Theodorides ile yaptığ 1 bir konuşmada aktardıkları ise o dönem halklarının hislerini göstermesi bakımında çarpıcı, Milletler arasındaki rabıtanın yok olduğunu göstermesi bakımından da önemlidir. Bahsi geçen konuşmada; Talat Paşa, Avukat dostunu ve onun aracılığı ile diğer Rum asıllı vatanseverleri ihtilal komitesine girmeye davet etmiştir. Avukat Marko: Abdülhamid idaresinin Türkiye'yi yıkıma götürdüğünü, meşruti bir düzenin ise Türkiye'nin yeniden ayağa kalkmasına sebep olacağını ve Rumeli'de yeniden güçlü bir idare tesis edileceğini, bundan dolayı da ihtilale yardım edecek tek bir Yunanlı bulunamayacağ 1 cevabını vermiştir (Mehmet Talat Paşa: 2013: 17). Avukat Marko’nun ifadesinde cisimleşen gayrimüslim tebaanın bu tutumunda, kuşkusuz millî devlet kurma/sınırları genişletme düşüncesiyle birlikte, büyük devletlerin de etkisi vardır (Sultan Abdülhamid 2011b: 2532).

Bâbıâli tarafından asayişi temin etmek maksadıyla askerî güç kullanılması ise çeşitli milletler tarafindan engellenmeye çalışmış, bundan dolayı da Osmanlı Devleti bu bölgede istenilenleri yapma noktasında zayıf kalmıştır. Goltz Paşa makalesinde, idarenin düzeltilememesi ve asayişin sağlanamaması noktasında suçun Osmanlılarda olmadığını uzun uzun açıklamıştır.

“Avrupa'da umûmiyetle zann olunduğu üzere Makedonya'da görülen fenâlık idâre-i Osmâniye'nin noksânından ileri geliyor ise Avusturya ile Rusya Devletlerinin ahîran vukû'a gelen ve icrâsına bede' olunan ıslâhât i'tilâfindan memnûniyet-i umûmiyeyi mûcib bir hüsn-i netîce istihsâl olunabilir. Şurası hafì değildir ki idâre-i Osmâniye'nin noksânından en ziyâde mutazarrır olması lâzım gelen millet yine millet-i hâkime olup istinâd edecek kimsesi olmayan ve mükellefiyet-i askeriye ile beraber en ă̆lr tekâliff-i emîriye tahtında bulunan Osmânlılardır. Milel ve cemâ'ât-ı sâ'ire için idâre-i Osmâniye sert ve ağır değildir. Yunan ve Bulgar ve Sirb ve sâ'ir milletlerden olup da hükûmet-i Osmâniye'ye karşı irtikâb ettikleri fenâlıklarından dolayı terk-i diyâr edenlerin kendi milletleri nezdinde râhat ve huzûr bulamayıp yine hükûmet-i Osmâniye'ye dehâlet ettikleri nâdir değildir. Milel-i mezkûre cümleten Osmânlıların sâhib-i lütf u kerem ve çabuk unutur ve memnûniyetle mu'âvenet eder bir millet olduğunu bilirler. Çünkü zu'afâya izhâr-l merhamet ve şefkat âdât-ı milliye-i Osmâniye'dendir ve yâhûd istenilirse ahlâk-ı mağrûrânelerindendir denilebilir. Bir de ahâlî-i Hiristiyâniye'den her biri gerek mensûb olduğu kilise ve me'mûriyet-i rûhâniyesi yanında ve gerekse belli başlı zînüfûzlar ve konsoloslar ve sefirler nezdlerinde istinâd edecek birkaç kuvvet bulabilip kendileri de zahrlarında olan işbu kuvvetler nisbetinde hâ'iz-i nüfûz ve iktidâr bulunurlar. Bu tafsîlâttan Balkan Mes'elesi'nin halli yalnız mâliye adliye ve idâre umûrunun ıslâhıla mümkin olamayacağı müstebân olur. Ahvâl-i hâzıranın sebeb-i aslîsi karşılarında daha metîn ve şedîd kuvvet görmediklerinden rekabete düşen ve yekdiğerine tefavvukla muzafferiyet ve galebeyi elde etmek ümmîdine çalışan cemâ 'atlerin tehyîc edilmiş olan iddi ' $\hat{a}-y l$ millîleridir." (BOA Y.PRK. MYD. 26/97: 3).

Görüldüğü üzere Goltz Paşa Osmanlı idaresinde asıl sıkıntıyı çekenlerin Müslümanlar olduğunu belirtmekte, Hristiyan unsurların daha rahat bir yaşamlarının olduğunu ifade etmektedir. Paşa, gayrimüslim tebaanın Müslümanlara göre daha iyi durumda olduğunu, bölgelerinde sıkıntı çıkarıp ırkdaşlarının yanına göç eden kimi toplulukların dahi daha sonra yeniden Osmanlı yönetimine iltica ettiklerini belirtmektedir. $\mathrm{Bu}$ durum aslında Balkanlar üzerinde ne derece müsamahakâr bir siyaseti takip edildiğini açık bir şekilde göstermektedir. Paşa'ya göre Osmanlıların lütufkar bir yönetim anlayışının olması ve işlenen fenalıkların devlet tarafından affedileceğinin gayrimüslimler tarafından bilinmesi, onların sürekli problem kaynağı olmasını beslemektedir. Ayrıca gayrimüslim tebaanın kiliseler, konsolosluklar ve Avrupalı güçler nezdinde buldukları destekle nüfuzlarını ve iktidarlarını artırmaları, devletin alacağı hukukî, malî ve adlî tedbirlerle Balkan problemini, çözülmesi yolunda engeldir.

Osmanlı Devleti'nde Müslümanlarla Hristiyanların Tanzimat döneminde yapılan düzenlemelerle eşit haklara sahip yurttaşlar olarak kamudan yararlanmalarının yolu açılmasına rağmen, angarya işler genel itibariyle Müslümanların üzerinde kaldı. Taraflar arasında ortak bir gelecek düşüncesi olmadığından, vatan uğruna kanlarını döken ve bundan dolayı genç erkek nüfusunun önemli bir kısmını kaybeden Müslüman köyler sefalet içinde iken, yanı başındaki Hristiyan köyleri en karışık dönemlerde bile bayındır bir haldeydi (Waylet-Jach, 2004: 211). Ancak Rusya'nın ve batılı güçleri de desteğini alan milletler için tebaası oldukları devletin iyi idaresi veya iyi bir idare tesis etmeye dönük faaliyetleri bir anlam ifade etmiyordu. Onların tek politikası daha fazla taviz ve toprak elde etmeye dönük olduğundan, Osmanlı Devleti'nin iyi niyetle ortaya koymuş olduğu bütün çabaları akim kalmıştır. Paşa: 
"Hiçbir vakit Bulgarlar otuz sene evvelîsi teşkîl-i kuvve-i karîbeye gelmiş olan büyük Bulgaristan hulyâsından bilâsebeb vaz geçmezler. Hiçbir zamân Yunan unsuru yüzlerce seneden beri hâ'iz olduğu kademden sarf-l nazar etmez. Hiçbir ân Sirblılar bahâdır İstefan Duşan zamânında olan vekâyi 'i mühimmeyi unutmazlar. Hiçbir vakit Arnavudlar ahâli-i kadîme-i asliyeden bulunmak azamet ve gurûrunu terk ederek âharın taht-l idâresine girmezler bunlardan başka yeni türeyen ve dikkate şâyân olan Koçu Valah nâmındaki Ulah ahâlı dahi iddi'â-yı mevcûdiyete kıyâm eylemiştir.” (BOA. Y.PRK. MYD. 26/97: 3-4).

tespitiyle bahsi geçen milletlerin emellerini özetlemiştir. Balkan meselesinin halledilme zorluğu esasında tam da Paşa'nın belirtmiş olduğu üzere Balkan milletlerinin gayeleriyle doğrudan alakalıdır. Paşa'ya göre söz konusu meselelerin kavranılabilmesi için Balkan milletlerinin amaçlarının üzerinde önemle durmak gerekmektedir. Birbirlerini pek de sevmeyen hatta Bulgar ve Yunanlılar örneğinde olduğu gibi birbirinden nefret eden milletlerin, Osmanlı Devleti'nin bir vilayeti olan Makedonya üzerinde hak sahibi olduğunu iddia etmesi ve bu bölgede yaşayan halkların nüfus bakımından birinin diğerine üstünlük sağlayamaması esasında bölgede yaşanacak bir çatışmanın ne derece yıkıcı olacağını da gösteren bir husustur. Ayrıca Balkan hükümetlerinin birbirlerine ${ }^{8}$ ve Osmanlı Devleti'ne karşı takip etmiş oldukları politikalar, Osmanlı yönetiminin atmış olduğu adımların neden istenen neticeyi vermediğini gösterir (Bkz. BOA, Y.PRK. MYD., 26/97). Goltz Paşa'ya göre böyle bir coğrafyada muharebeden çekinmeyerek meydana çıkmanın daima iyi siyasî karşılığı olmuştur. Paşa bu fikrini desteklemek için şu örneği verir:

“Ĕger 1903 senesi Sarakof idâresinde olan Bulgar eşklyâsının şiddet ve kuvvet kesb ettiği ve emâret tarafindan mütemâdiyen mu'âvenet olunduğu sirada muhârebeye karâr verilmiş olaydı bugün Balkan Şibh-i Cezîresi'nde ă̆leb ihtimâl sulh u âsâyiş hüküm-fermâ bulunur idi. Fakat şimdiki hâlde Makedonya mevâki'inde artık silâh altında kuvve-i külliye bulundurmak ve ciddiyet ve şiddetle alay kumanda ettirmekten başka çâre yoktur. Sükûn ve âsâyiş mûcib-i ıslâhât âsâr-ı hasenenin husûlünü bâdî olursa da yalnız bununla mes'elenin halli te'mîn edilemez. Cünkü vâsita-i âsâyiş âsâyiş istemeyenlere karşı hükümsüzdür." (BOA. Y.PRK. MYD. 26/97: 9).

Avrupalı devletler Balkan problemlerine sürekli karışmış ve menfaatlerine göre olayları yönlendirmeye çalışmışlardır. (BOA., EE. KP., 36/3525; MC. Yz. K0271: 1). Nitekim İngiltere'nin Berlin Antlaşması'ndan önce, antlaşma sırasında ve antlaşmadan sonra takip etmiş olduğu siyaset bu açıdan önemli bir delildir (Sultan Abdülhamid 2011a: 68). İngiliz siyasetindeki sürekli değişim, Sultan II. Abdülhamid'in dış politikada çekilen birçok sıkıntının sebebini bu devlete bağlamasına sebep olmuştur. Sultan'a göre Rusya ile Osmanlı Devleti arasında çıkan son savaşın müsebbibi İngiltere'dir. İngiltere bu savaşı çıkarmakla kalmamış Berlin'de, Ayestefanos Antlaşması'nın yalnızca kendi çıkarlarını zedeleyen kısımlarını kaldırtıp, Osmanlı Devleti'nin başına bela olacak Ermeni Meselesinin zeminini oluşturan bir madde ekletmiştir. Antlaşmadan sonra da Balkanlarda, kendilerinin aleyhine olacak şekilde Prens Alexander ile iş birliğine gitmiştir (Sultan Abdülhamid,

8 Balkan milletleri arasındaki anlaşmazlığa bir örnek olarak 1885'in kasımında Sırp ve Bulgar Prenslikleri arasında çıkan savaş gösterilebilir. 2011b: 26-27). Sultan’ın bu düşüncesini İngiliz devlet adamlarının zaman zaman vermiş oldukları beyanatlar tasdik etmektedir. Örneğin İngiltere Başvekili Lord Salisbury’nin Bulgarları İngiliz siyasetine yakınlaştırmak için parlamentoda yaptığı konuşma, tam da Bulgarlar üzerinden Balkan siyasetini dizayn etmeye dönüktür. Hicri 1309 tarihli bir belgede bu olaya değinilmiştir. Buna göre Osmanlı devlet adamları, Bulgarların tek başına Balkan meselesini çözebileceğini belirten Salisbury'nin, Bulgarları kışkırttığı ve çıkabilecek hadiseler nedeniyle Bulgar halkının sıkıntı çekebileceğini düşünmektedir (BOA. Y.PRK. TKM. 22/2). Balkanlardaki siyasî durum göz önüne alındığında, Rusların veya büyük devletlerin desteğini alamayan bir Bulgar Prensliğinin Salisbury'nin belirttiği gibi Balkan meselesini çözmesi bir tarafa, varlığını devam ettirmesi dahi zordur. Bulgar Prensliğinin kendi başına varlığını devam ettirme noktasında zayıf kalacağı düşüncesi, onları, bu dönemdeki siyasî denklem içinde Rusya veya Avusturya'nın yanında, gözetiminde veya tahakkümünde olmasını kaçınılmaz kılmaktadır (Küçük Mehmet Sait Paşa 2019: 457). Sultan II. Abdülhamid'in düşüncesi de bu yöndedir (Sultan Abdülhamid 2011a: 84). Balkan problemlerini Osmanlı Devleti üzerinde tahakküm kurmaya dönük siyasî bir koz olarak kullanan batılıların çalışması Paşa'nın da dikkat ettiği bir husustur. $\mathrm{Bu}$ bağlamda Goltz Paşa Makedonya'ya Avrupalı bir genel valinin tayin edilmesinin iyi bir sonuç doğurmayacağ 1 düşüncesindedir. Ona göre, Osmanlı hükümeti ile irtibatı olmayan veya çok zayıf olan bir valinin yabancı güçlerin nüfuzunda olacağı aşikardır. Ayrıca Avrupalı devletlerle sürekli irtibatta olan ve onları memnun etmeye çalışacak olan valinin genel bir memnuniyet ortamı oluşturması da beklenen bir durum değildir. Paşa, Osmanlı Devleti'nde eğer Avrupa devletleri müsaade ederse Makedonya gibi problemli bir bölgeyi yönetebilecek birçok memurun olduğunu belirtmektedir.

“...beyân olunduğu üzere milel-i muhtelife ahvâlinin müsâ'ade ettiği derecelerde dâhil-i memlekette sükûn ve âsâyişi muhâfaza edebilmeğe muktedir me'mûrîn yok değildir. Ve îfâ-yı vazîfe için arzu ve gayretleri dahi berkemâl olup Avrupa'nın me'mûrîn-i Osmâniye'ye karşı ibrâzına hâhiş-ker olduğu sû-i emniyeti mûcib meydânda bir şey yoktur. Me 'mûrîn-i mezkûreden Almanya'da tahsîl etmiş erbâb-l şiddet ve basîretten Rahmi ve Şükrü Paşalarl ve kezâ Almanya hizmet-i askeriyesinde bulunmuş olup Üçüncü Ordu-yı Humâyûn Müşîr Vekîli hayr-hâh ve terbiye-i dakîkayı hâ'iz Es 'ad Paşa'yı ve Kosova Vâlîsi aliyyü'l-a 'lâ Mahmûd Şevket Paşa'yı ve Siroz mevki 'inde Müşîr İbrâhîm Paşa'yı ve bir Yunan çetesinin bir eşkıyâ köyüne ta 'arruz etmesinden dolayı Manastır'da olan me'mûriyetinden alınan aliyyü'l-a 'lâ Hâdî Paşa'yı tezkâr ve şimdiki hâlde isimleri hâtıra gelmeyen diğerlerinin dahi bulunduklarını beyân ederim." (BOA. Y.PRK. MYD. 26/97: 10).

diyerek, uygun koşullarda kimlerin görev yapabileceğini de isim isim belirtir. Burada dikkati çeken bir hususu vurgulamak gerekir ki o da, belirtilen isimlerin genel itibariyle Almanya'da eğitim görmüş olmaları ve Alman siyasetine yakın olmalarıdır. Paşa Balkan Meselesi'nin hallolabilmesi için ismini saydığı kişilerin Bâbıâli tarafından desteklenmesi gerektiğini ve alınan tedbirlerden netice alınamazsa, bu durumda bunların hepsinin memuriyetten

Bkz. Ahmet Cevdet Paşa, Tezakir: 40 Temime, (Haz. Cavid Baysun), TTK, Ankara 1991, s. 226-227. 
alınmasını belirterek, böylece devlet tarafından her şeyin yapılmış olduğunun büyük devletlere de gösterilmiş olacağını ifade etmektedir. ${ }^{9}$ Osmanlıların haklı olarak kendilerine sunulan haksız tekliflerden yakındıklarını ve şikâyet ettiklerini belirttikten sonra, "Kuvvetli olun $k i$ umumun hakl muamelesine nail olasınız" ihtarında bulunur. Osmanlı Devleti'nin geleceği hakkında tahminlerde bulunmanın güç olduğunu belirten Goltz, Osmanlı Devleti 'nin Zaaf ve Kuvveti adlı eserinde, Viyana kapılarına kadar dayanan Türklerin o günün şartlarında düşmanlarına mukavemet edemeyerek büyük topraklar kaybettiğini, bu darbelerin en mühiminin de 1877-78 Osmanlı Rus Harbi ile geldiğini belirtikten sonra, bu gerçekten hareketle o günün şartlarında direnemeyen Osmanlıların, bugünün şartlarıyla mukavemet edemeyeceklerini söyleyenlerin yanıldı̆̆ını belirtmektedir. $\mathrm{Bu}$ durumun nasıl mümkün olabildiğini ise ancak imparatorluğun tarihinin incelenmesi ile ortaya çıkacağını ifade eder (Goltz ty: 15; Günay 1991: 32).

Sonuç olarak Goltz Paşa'nın izlenmesini tavsiye ettiği siyaset Osmanlı Devleti için geçmişte uygulanması kolay olan bir politika iken, Her millete bir devlet söyleminin uluslararası siyasettin temel problemlerinden biri haline geldiği 19 ve 20. Yüzyıllar (Hobsbawn 2000: 125-126) süresince devletteki zafiyetlerden dolayı zor bir politikayd. Osmanlı Devleti için özellikle 19. yüzyılın ikinci yarısı, büyük devletlerin baskısının arttığı ve her vesileyle devletin içişlerine karışıldığı bir dönem oldu. Sultan II. Abdülhamid dönemi ise Hristiyan tebaanın büyük oranda bağımsız ulus devletlere dönüşmesiyle başladı. $\mathrm{Bu}$ açıdan Sultan II. Abdülhamid dönemi balkan siyasetinin birçok zorlu tarafi bulunmaktaydı. Bütün iç ve dış politika zorluklarına rağmen Goltz Paşa Osmanlı Devleti için yaptığı: "Osmanlı Devleti, aslî özelliklerini kaybetmemiş, yiğit, kanaatkâr, basit ve rızacı bir kavim tabiatında, yine başta mevcut olan menfaat hissi ile fetihçi geleneklerden doğan hakimiyet hissiyatında ve örf adet ile teyit edilmiş, halifeye kayıtsiz itaat eden bir toplum yapısındadır. İki asırdan beri vukua gelen toprak kaybı ve karışıklıklar, onun tükenmişliğine delil olamaz." (Goltz 2012: 55) değerlendirmesi ile hasta adam tabirinin yerinde olmadığını ve devletin bütün güçlüklere rağmen varlığını devam ettireceği tespitinde bulunmuştur.

\section{Değerlendirme}

Osmanlı modernleşmesi bir taraftan devletin aksayan yönlerini düzeltmek için yol alırken, diğer taraftan yeni problemlerin de kaynağını oluşturuyordu. Örneğin on dokuzuncu yüzyılda yapılan düzenlemeler (TanzimatIslahat Fermanları) Osmanlı devlet adamları tarafindan devletin bütünlüğünü korumaya dönük birer adım olarak görülse de klasik toplum düzenini sarsan ve bir anlamda anlamsız kılan sonuçlar doğurdu. Avrupalılar nezdinde politik eşitlik anlamı taşıyan bu belgeler, daha sonraki süreçte özellikle balkan ulusları tarafından bağımsızlığa giden süreçte birer mihenk taşı olarak kullanıldı.

Tanzimat devri boyunca Balkanlarda hızla gelişen etnik aidiyet ve ulus devlet anlayış1 1877-78'de meydana gelen Osmanl1-Rus savaşından sonra vücut buldu. Her ne kadar Yunanistan'ın bağımsızlığı daha eski tarihlere dayanıyor olsa da Osmanlı'nın Avrupa topraklarını çok etkilemeyen, Mora yarımadasıyla sınırlı bir devletti. Ancak bahsi geçen savaştan sonra Osmanlı Devleti balkanlardan büyük oradan çekildi. Elinde kalan balkan vilayetleri ise Selanik hariç problemliydi. Savaştan sonra imzalanan Berlin Antlaşması bölgeyi siyasî olarak yeniden dizayn etmiş olsa da bir barış ortamı doğurmamıștı. Bu anlamda Sultan II. Abdülhamid dönemi balkanlar tam anlamıyla bir barut fiçısı idi.

Makalenin konusu olan ve Goltz Paşa'nın "Balkan Meselesi" serlevhasıyla Alman Die Woche isimli haftalık gazetede kaleme aldığı makalede Balkan Meselesi'nin hangi şartlarda ortaya çıktığı ve çözümü için ne suretle hareket edilmesi gerektiğine dair tafsilatlı bilgiler verilmektedir. Sultan II. Abdülhamid'in yumuşak güç kullanımına yönelik politikasına karşı, Goltz Paşa Osmanlı Devleti'nin haklılığını ortaya koyabilmesinin yegâne yolunun güçlü olabilmesinden ve gücü kullanabilmesinden geçtiğini belirtmektedir. Geçmişten günümüze uluslararası siyaset bu anlamda incelendiğinde bu tespitin çok yerinde olduğu ortadadır. Nitekim askerî ve ekonomik olarak zayıf düşen Osmanlı Devleti'nin Balkan topraklarını elde tutabilmek için ortaya koyduğu çaba ve hüsnü niyetin, batılılar tarafindan sürekli olarak görmezden gelindiği tarihin tescilindedir. Bulgarların uygulamış olduğu vahşeti görmezden gelen büyük güçlerin, Osmanlı Devleti'nin kendi topraklarında sükuneti sağlamaya dönük faaliyetlerine şiddetle karşı çıkmaları esasında Osmanlı Devleti'ne karşı örtülü bir saldırı içinde olduklarını gösterdiği gibi, Doksan Üç Harbi ve I. Balkan Savaşı esnasında Müslüman ahalinin uğramış olduğu mezalimi görmezden gelmeleri de hangi duygularla hareket ettiklerini ve nasıl bir siyasî amaç güttüklerini göstermesi bakımından önemlidir. Goltz Paşa'nın düşüncesine göre, uluslararası arenada devletler ancak güçleri oranında saygı görmektedirler. Paşa'ya göre, Osmanlı Devleti'nin Balkanlardaki varlığı, nasihat siyasetinin ve idarî tedbirlerin yanı sıra askerî güç kullanmasına bağlıdır. Askerî güç ile desteklenmeyen politikalar ise hiçbir netice vermeyecektir. Son olarak, Paşa'nın askerî seçeneği olabildiğine öncelemesinin haklı nedenleri olmakla birlikte, Alman silah şirketleri ile ilişkisinin bu düşünce üzerindeki etkisinin ne olduğu da incelemeye değer bir konudur.

\section{Kaynakça}

Arşiv Evrakı

BOA, Y.PRK. MYD., 26/97.

BOA., Y.PRK. BŞK., 64/53.

BOA, HR. SYS. 358/4.

BOA., A. MTZ. (04), 20/16.

BOA, Y. EE. d., 1016.

BOA, Y.PRK. TKM., 47/18.

BOA, TRF. I. A., 12/1189.

BOA. İ. HUS., 108/28.

BOA., Y. PRK.HR., 23/53.
9 “Balkan Mes'elesi'nin olabildiği kadar müsâ id bir sûrette hallolunabilmesi me 'mûrîn-i mezkûrenin hedef olduklarl șikâyetlerden dolayı mes'ûl bulundukları Bâb-ı Âlî cânibinden kuvve-i zahriyeye nâ 'il olmalarına ve dûçâr-l su 'ûbet ve müşkilât edilmelerine ve bununla da olamadığı hâlde cümlesinin me'mûriyetlerinden alınarak her seyin yapılmış olmasına menûttur.” BOA, Y.PRK. MYD., 26/97, s. 7. 
BOA., Y. PRK. HR., 23/55.

BOA., TFR. I. AS., 7/663.

BOA., EE. KP., 36/3525.

BOA. Y.PRK. TKM., 22/2.

MC.Yz. K0271 (Goltz, Balkan İğtişaşatı ve Esbabı, Atatürk Kitaplığ 1$)$

\section{Telif Eserler}

Ademi, R. (2018). Sultan II. Abdülhamid'in Balkan Siyaseti, Sultan II. Abdülhamid ve Dönemi Uluslararası İlmî Toplantısı Bildirileri, İstanbul, 181-195.

Adanır, F. (2006). Makedonya Sorunu, İstanbul: Tarih Vakfı Yurt Yayınlar1.

Ahmet Cevdet Paşa. (1991).Tezakir: 40 Temime, Haz. Cavid Baysun, Ankara: TTK Yayınları.

Armaoğlu, F. (2006). 19. Yüzyll Siyasî Tarihi (1789-1914), İstanbul: Alkım Yayıne.

Arslan, Ali. (2003). Makedonya'da Rum-Ulah Çatışması, Yakın Dönem Türkiye Araştırmaları, Sayı 4, 1-25.

Bağçeci, Y. (2014). İngiltere Parlamento Tutanaklarında 1876 Bulgar İsyanı, JASS, Say1 24, 211-235.

Bayrak, M. (2002). Osmanlı Arşivleri Işığında Rum İsyanı Sirasında Avrupalı Devletlerin Tutumu, Osmanl, Cilt 2, Ankara: Yeni Türkiye Yayınları, 71-86.

Çatma, B. (2019). II. Meşrutiyet Dönemi Osmanlılık Düşüncesinin Evrimi: Abdulkadir Câmi (Baykurt) Bey Örneği, anemon, 7/6, s. 53-58.

Erdoğdu, T. (1999). 1856 Paris Kongresi-1878 Berlin Kongresi Arasında Osmanlı Dış Politikası, Çağdaş Türk Diplomasisi: 200 Yıllık Süreç, Ankara 15-17 Ekim 1997, Ankara: TTK, 150-172.

Engin, Vahdettin. II. Abdülhamid ve Dış Politika, İstanbul: Yeditepe Yayınları, 2011.

Goltz, C. (ty.). Osmanlı Devleti'nin Zaaf ve Kuvveti, Müt. Zaimzade Hasan Fehmi. Mısır: Matbaatü'l Futuh.

. (2012). Yirminci Yüzyılın Başında Osmanlı Alman İlişkileri "Golç Paşa'nın Hatıratı, (Haz. Faruk Y1lmaz), İstanbul: İz Yayıncılık.

Gülden, İ. K. (2019). Abdülhamid Dönemi Osmanlı Karadağ İlişkileri, Meriç Uluslararası Sosyal ve Stratejik Araştırmalar Dergisi. 3/6, 16-35.

Gümüş, M. (2019). Sultan II. Abdülhamid Dönemi Osmanlı Diplomasisinde Denge Arayışları ve Osmanlı Dış Politikası, Tanzimat'tan Günümüze Olaylar ve Kişiler Ekseninde Türk Hariciyesi, (Ed. İ. Sami Yuca-Hidayet Kara), İstanbul: Kitabevi Yayınları, 221-259.

Günay, S. (1991). Colmar von der Goltz'un Gözüyle Osmanlı Devleti ve Geleceği, Atatürk Dergisi, 1/ 5, 2641.

Hacısalihoğlu, M. (2018). Balkanlarda Muhalif Hareketler ve Sultan Abdülhamid, Sultan II. Abdülhamid ve Dönemi Uluslararası İlmî Toplantısı Bildirileri, 107115.
Hobsbawn, E. J. (2000). Milletler ve Milliyetçilik Program, Mit, Gerçeklik, İstanbul: Ayrıntı Yayınları.

Jorga, N. (2009). Osmanlı Imparatorluğu Tarihi, Cilt 5. (Çev. Nilifer Epçeli), İstanbul: Yeditepe.

İnalcık, H. (2005). Türkler ve Balkanlar, Balkan Türkoloji Araştırmaları Merkezi, Prizren, 20-44.

Kara, H. (2013). Sultan II. Abdülhamid Dönemi Osmanl Kara Ordusu (1876-1908), Erzurum: Atatürk Üniversitesi Sosyal Bilimler Enstitüsü, Yayınlanmamış Doktora Tezi.

Karpat, K. (2004). Balkanlar'da Osmanlı Mirasl ve Ulusçuluk, (Çev. Recep Boztemur), Ankara: İmge Yayınevi.

(2002). Etnik Kimlik ve Ulus Devletlerin Oluşumu, Osmanl, Cilt 2, Ankara: Yeni Türkiye Yayınları.

(2006). Çok-Etnisiteli Ulusallık Dışı İslam Devletinde Etniklik Sorunu: Osmanlı Devleti'nde Etnik Kimliğin Sürekliliği ve Yeniden Biçimlendirilmesi, Osmanlı'da Modernleşme ve Uluslaşma. Ankara: İmge Kitabevi.

Kerimoğlu, H. T. (2007). Kilise ve Mektepler Kanunu Örneğinde II. Meşrutiyet Döneminde İttihatçı-Rum İlişkileri, ÇTTAD, VI/14, 3-25.

Kılıç, S. (2006), Bir Osmanlı Aydınının Arnavutluk’a Dair Görüş ve Düşünceleri, OTAM. 19/ 19, 258-270.

Kuran, E. (1994). II. Abdülhamid'in Büyük Devletlere Karş1 Uyguladığı Siyasetin Esasları, Sultan II. Abdülhamid ve Devri Semineri 28-29 Mayls 1992. İstanbul: Edebiyat Basımevi.

Küçük Mehmed Said Paşa (2019). Küçük Mehmed Sa’id Paşa'nın Hâtırâtı, (Haz. Mustafa Gündüz), Cilt 1, İstanbul: Ketebe.

Lewis, B. (1984.). Modern Türkiye’nin Doğuşu, (Çev. Metin Kiratli), Ankara: TTK.

Mahmut Celaleddin Paşa (1983). Mir'at-ı Hakikat, Haz. İsmet Miroğlu, İstanbul: Bereket Yayınevi.

Ortaylı, İ. (2017). Tanzimat Dönemi Balkanlar'da Ulusal Kiliseler ve Rum-Ortodoks Kilisesi, Osmanlı'da Milletler ve Diplomasi Seçme Eserler III, İstanbul: Türkiye İş Bankası Yayınları.

(1985). Balkanlar'da Milliyetçilik, Tanzimat'tan Cumhuriyet'e Türkiye Ansiklopedisi. Cilt 4, İstanbul: İletişim Yayınları.

(2017). Ortodoks Kilisesi, Osmanlı'da Milletler ve Diplomasi Seçme Eserler III. İstanbul: Türkiye İş Bankası Yayınları.

(2008). İlk Osmanlı Parlamentosu ve Osmanlı Milletlerinin Temsili, Osmanlı'da Değişim ve Anayasal Rejim Sorunu Seçme Eserler II. İstanbul: Türkiye İş Bankası Yayınları.

Özcan, U. (2012). "II. Abdülhamid'in Diplomasisinde Yüksek Topuklar: Karadağ Prensesi Milena ve Sultan II. Abdülhamid". OTAM. Ankara: 32/ 32, 113-139.

Salih Münir Paşa (2015). Geçmiş Zamanlar: II. Abdülhamid Devri Osmanl Diplomasisi, Istanbul ve Paris 
Hatıraları, (Haz. Ali Birinci-Selma Günaydın), Ankara: TTK.

Saatçi, M. B. (2009). Balkan Ulusçuluklarına Dair Bir Değerlendirme: Farklı Uluslar Farklı Usûller, Karadeniz Araştırmaları. 6/23, 13-28.

Sertoğlu, M. (2001). Mufassal Osmanll Tarihi, Cilt 5, Ankara: TTK.

Sezer, H. (2002) Mora İsyanı ve Yunanistan'ın Bağımsızlığı (1821-1829), Osmanll. Cilt 2, (s. 87-93), Ankara: Yeni Türkiye Yayınları.

Shaw, S. J.-Shaw, E. K. (2006). Osmanlı Imparatorluğu ve Modert Türkiye, Cilt 2, İstanbul: e-Yayınlar1.

Sultan II. Abdülhamid. (2010). Siyasî Hatıratım, İstanbul: Dergâh Yayınları.

Sultan II. Abdülhamid. (2011). Devlet ve Memleket Görüşlerim, (Haz. A. Atilla Çetin), İstanbul: Çamlıca.
Yetim, F. (2011). Osmanlı İmparatorluğu'nun Dağılma Döneminde Balkan Milliyetçiliği ve Büyük Güçler, Selçuk Üniversitesi Sosyal Bilimler Enstitüsü Dergisi, 25, 285-296.

Bonyar W.-Ernst J. (2004). Imparatorluk Stratejileri ve Ortadoğu, Çev. Vedat Atülla, İstanbul: Chiviyazıları Yayınevi.

\section{Online Eserler}

Bostan, İdris. "Navarin", $D \dot{I} A$, https://cdn.islamansiklopedisi.org.tr/dosya/32/C32010 633.pdf. (Erişim tarihi 08.05.2019).

Gencer, Ali İhsan. "Berlin Antlaşması", $D \dot{I} A$. https://cdn.islamansiklopedisi.org.tr/dosya/5/C05 002148.pdf (Erişim tarihi: 11.06.2019)

Küçük, Cevdet. "Balkan Savaşı”, $D \dot{I} A$,

https://cdn.islamansiklopedisi.org.tr/dosya/5/C050017 85.pdf (Erişim Tarihi: 12.06.2019.) 


\section{Ek 1:}

Y.PRK.MYD, 26/97

\section{Bihi}

\section{fî 12 Mart 1908 Târîhli "Die Woche Nâm Alman \\ Cerîdesinde Münderic Balkan Mes'elesi Hakkında Golts Paşa Tarafindan Yazılan Makâlenin Tercümesidir}

Sulh ve âsâyişin te'mîn-i muhâfaza ve idâmesi için her türlü fedâkârlık ihtiyâr olunduğu hâlde hiçbir fâ'ide istihsâl olunamayan ve vesâ'it-i insâniyet-kârâne ile de halli mümkin olamayan mesâ'il-i siyâsiye var ise o da Balkan Mes'elesi'dir. El-Yevm şekl-i hâzırı iktisâb eden işbu mes'ele ortalı sulh ve âsâyiş-i tâmm içinde bulunduğu ve meydânda hiçbir sebeb-i zâhiri görülmediği bir ânda Rûmeli-i Şarkî'nin bağteten taht-1 idâre-i Devlet-i Aliyye'den infikâk ettirildiği fî 18 Eylül 1885 tariinde ser-zede-i zuhûr olan Filibe Vak'asıyla ibtidâr eylemiştir. Ahvâle vâkıf ve Devlet-i Aliyye'ye dost ve muhibb olanlar evânda serî́ bir nisbette bulunmasını ya "nî der-akab Rûmeli-i Şarkî Vilâyeti'ne kuvvet sevk eylemesini devlet-i müşârun-ileyhâya tavsiye etmekten geri durmamışlardır. Bende bu tavsiyeyi etmiștim. Bağteten vukû'a gelen işbu hâdisenin bidâyet-i zuhûrunda fí'l-hakîka uzun müddet devâm edecek ihtimalat-1 siyâsiyeye intizâren mes'elenin hakîkati anlaşılıncaya kadar te'ennî ile hareket etmekten ise cür'et-kârâne fa'âliyet gösterilmesi daha ziyâde te'mîn-i maksada hizmet eder. Tehlikeli zamânda cür'et-kârâne hareket ekseriyâ kâr-1 âkildir.

Erbâb-1 vukûftan birisi vak'a-i mezkûre üzerine eğer Bâbıâli Rûmeli-i Şarkî hâdisesine bilâ-i'tirâz sükût edecek olursa Ayastefanos Musâlahası mes'elesi tekrâr meydâna konacak demiştir. Ma'lûm olduğu üzere ayastefanos Musâlahası Makedonya'nın kâffesiyle Kavala civârında Adalar Denizi'ne müntehî ve Yanya Vilâyetiyle Arnavudluk ve Tesalya Kit'ası ve Edirne Vilâyeti'nin bir kısmı hâric olarak Balkan Şibh-i Cezîresi'nin aksâm-1 mütebâkiyesini hâvî bir büyük Bulgaristan vücûda getirmiş idi. İşbu vüs'ati ibkâ edilmiş olaydı emâretin civâr-1 hükûmetlere nisbetle pek kuvvetli bulunacağı der-kâr idi. Berlin Kongresi şu parlak istikbâl hayâlâtını bozup Bulgaristan Emâreti'ni Balkan silsilesinin şimâl kısmı ve şimdiki makarr-1 emâreti olan Sofya ile tahdîd ederek hükûmât-1 sâ'ire-i Hıristiyâniye ile başlamakta olan reakbete bir sedd-i mâni“ teşkîline çalışmıştır.

(Sâhib-i memâlik-i Devlet-i Aliyye-i Osmâniye kuvvet ve şiddetle tekrâr teşkîl edemeyecek bir hâle getirilmezden evvel sedd-i mâni'-i mezkûr kaldırıldığından milel-i muhtelife denizlerinin tehâcüm ve galeyânına ma'rûz kalmıştır. Fî'l-hakîka vekâyi`de bunu mü’eyyiddir) Vak'a-i mezkûreden beri yirmi üç sene mürûr eylediği hâlde bu müddet zarfinda Balkan Şibh-i Cezîresi'nde dâ'imî bir âsâyiş-i tâmm vücûda gelmemiştir. Bazı zâhirî sükûnlarda sâlifü'z-zikr tavsiyemin savâb olduğuna şübhe eder idim. Fakat bugün artık kat'iyen emîn oldum.

Dersa'âdet'te hayr-hâhân-1 saltanat-1 seniyye bulunan süferâ ve maslahat-güzârlar Bâb-1 Âlî'ye teşebbüsât-1 ciddiye-i fi' ${ }^{\prime}$ iliyede bulunmamağı tavsiye etmişler ve şu sûretle tavsiyeden maksadları esâsen muhâfaza-i âsâyiş arzusunda olmağla beraber teşebbüsât-1 harbiye ve icrâât-1 kat'iyede bulunmak için kuvve-i Devlet-i Aliyye'nin gayr-1 kâfî olduğu zann-1 gayr-1 sahîhinde bulunarak Edirne civârında bir ordunun tahşîdi için Makedonya'da olan kuvve-i şâhânenin alınması îcâb etmekle kuvvetten hâlî kalan işbu tehlikeli fesede ocağının hemân galeyâna başlayacağından endîş-nâk olmalarından ileri gelmiş idi hâlbuki tavsiye ve tahmînleri doğru çıkmamıştır. O esnâda mevcûd olan hutût-1 muvâsale Vilâyât-1 Selâse'den Edirne cihetine kuvvet nakledilmesine gayr-1 müsâ‘id idi.

Edirne civârında bulunan kuvvâ-yı şâhâne Anadolu'dan sür'atle celb olunacak kuvve-i redîf ile takviye olunduğu hâlde mehâbet-i lâzıme ile ilerileyecek kuvvetli bir ordu vücûda gelebilir idi.

$\mathrm{Bu}$ sûretle hareket Avrupaca bir harb-i umûmîyi mûcib olmaz idi. Zîrâ Rûmeli-i Şarkî hatt-1 imtiyâzının tecâvüz edildiğini müte'âkib siyâsî tavassutun vukû'a geleceği derkâr ve Bâbıâli tarafından ișbu tavassuta memnûnen muvâfakat olunacağı âşikâr idi. Muhârebe başlamış ise derakab mütâreke olunur ve netîcesinde ağleb ihtimâl hükûmeti seniyyece ahvâl-i hâzıradan daha ziyâde fâ'ideli netâyic istihsâl olunarak Bulgar hırs u tamâ' 'na bir sedd-i mâni' çekilir idi işbu teşebbüsât yerine 1885 senesi Sırb-Bulgar muhârebesi esnâsında ordu-y1 humâyûna tedârikât-1 seferiyesini bi'l-icrâ Rumeli-i Şâhâne hudûdunda tahşif olunarak bir büyük muhârebede vukû'a gelecek olan telefâttan daha ziyâde vefeyâtı bâdî olan tifo hastalığıyla netîcelendir. Aynı sene zarfında yine tedârikât-1 seferiyeyi îcâb ettiren Yunanistan İhtilâfı vukû'a geldi mu'ahharan da birbirini müte‘âkib türeyen Bulgar ve Sirb ve Yunan eşkıyâları bî-çâre memlekete terakkî ve umrâna başlamak için mühlet ve huzûr ve râhat bulmak imkânı bırakılmadı. Bâbıâli tarafından te'mîn-i âsâyiş maksadıyla ibrâz olunan şiddet milel-i muhtelifenin Balkan hükûmât-1 sagîresi hakkında gösterdikleri kuvve-i ma'neviyeyi za'îfletmek husûsunda kusûr etmemiştir.

Zât-1 hazret-i pâdişâhînin efkâr ve niyat-1 sulh-cûyâneleri hükûmet-i seniyyelerinin tamâmiyet-i mülkiyelerine dokunur ahvâl bir tebeddülât-1 siyâsiye zuhûru endîşesi sâlifü'z-zikr tavsiyenin te'sîrini tenkîs etmekle muvâfik bir sûrette i'tilâf bulunarak on seneden ziyâde bir müddet için te'mîn-i sulh edildi. Ma'a-mâfîh Balkan Mes'elesi yine bâkî kald.

Ve Avrupa sulh ü müsâlemet-i umûmiyesi için daha tehlikeli bir devre inkılâb edip şu son senelerde milel-i muhtelife fesedeleri de tezâyüd ve eski kuvveti kesb ettiler. Hükûmet ve milletlerin tertîbâtında âsâr-1 za'af her ne kadar büyüklerin ulüvv-i şefkat ve merhametlerinden mütevellid olsa yine dûçâr-1 mücâzât ve ahz-1 intikâma sebeb olmaktan kurtulamaz.

Avrupa'da umûmiyetle zann olunduğu üzere Makedonya'da görülen fenâlık idâre-i Osmâniye'nin noksânından ileri geliyor ise Avusturya ile Rusya Devletlerinin ahîran vukû'a gelen ve icrâsına bede' olunan sslâhât i'tilâfindan memnûniyet-i umûmiyeyi mûcib bir hüsn-i netîce istihsâl olunabilir. Şurası hafî değildir ki idâre-i Osmâniye'nin noksânından en ziyâde mutazarrır olması lâzım geşen millet yine millet-i hâkime olup istinâd edecek kimsesi olmayan ve mükellefiyet-i askeriye ile beraber en ağır tekâlîf-i emîriye tahtında bulunan Osmânlılardır. Milel ve cemâ‘ât-1 sâ'ire için idâre-i Osmâniye sert ve ağır değildir. Yunan ve Bulgar ve Sırb ve sâ'ir milletlerden olup da hükûmet-i Osmâniye'ye karşı irtikâb ettikleri fenâlıklarından dolayı terk-i diyâr edenlerin kendi milletleri nezdinde râhat ve huzûr bulamayıp yine hükûmet-i Osmâniye'ye dehâlet ettikleri nâdir değildir. 
Milel-i mezkûre cümleten Osmânlıların sâhib-i lütf u kerem ve çabuk unutur ve memnûniyetle mu'âvenet eder bir millet olduğunu bilirler. Çünkü zu'afâya izhâr-1 merhamet ve şefkat âdât-1 milliye-i Osmâniye'dendir ve yâhûd istenilirse ahlâk-1 mağrûrânelerindendir denilebilir. Bir de ahâlî-i Hıristiyâniye'den herbiri gerek mensûb olduğu kilise ve me'mûriyet-i rûhâniyesi yanında ve gerekse belli başlı zînüfûzlar ve konsoloslar ve sefîrler nezdlerinde istinâd edecek birkaç kuvvet bulabilip kendileri de zahrlarında olan işbu kuvvetler nisbetinde hâ'iz-i nüfûz ve iktidâr bulunurlar. Bu tafsîlâttan Balkan Mes'elesi'nin halli yalnız mâliye adliye ve idâre umûrunun 1slâhıyla mümkin olamayacağı müstebân olur. Ahvâl-i hâzıranın sebeb-i aslîsi karşılarında daha metîn ve şedîd kuvvet görmediklerinden rekabete düşen ve yekdiğerine tefavvukla muzafferiyet ve galebeyi elde etmek ümmîdine çalışan cemâ'atlerin tehyîc edilmiş olan iddi'â-yı millîleridir.

Avrupa matbû‘âtı Balkan milel-i muhtelifesi beyninde zuhûr eden işbu rekabet ve tefavvuk-1 millî iddi'âsını hükûmet-i Osmâniye idâresinin yolsuzluğuna atfetmekte ise de son senelerde idâre-i Osmâniye daha iyi bir hâlde bulunmaktadır. el-Yevm Makedonya'da muktedir ve genç ve fa'âl askerî kumandanları ile me'mûrîn-i mülkiye îfâ-yı vazîfe etmektedirler. Mûmâ-ileyhim îfâ-y1 vazîfede serbest bırakılmış ve milel-i muhtelifenin iddi‘â-yı tefavvuklarından masûn bulunmuş olsalar âsâyiş-i umûmiyeyi muhâfazaya ve hasmın tecâvüzâtına hatve be-hatve mümâna'ate muvaffak olacakları der-kâr idi. Hiçbir vakit Bulgarlar otuz sene evvelîsi teşkîl-i kuvve-i karîbeye gelmiş olan büyük Bulgaristan hulyâsından bilâ-sebeb vaz geçmezler. Hiçbir zamân Yunan unsuru yüzlerce seneden beri hâ'iz olduğu kademden sarf-ı nazar etmez. Hiçbir ân Sırblılar bahâdır İstefan Doşan zamânında olan vekâyi‘-i mühimmeyi unutmazlar. Hiçbir vakit Arnavudlar ahâlî-i kadîme-i asliyeden bulunmak azamet ve gurûrunu terk ederek âharın taht-1 idâresine girmezler bunlardan başka yeni türeyen ve dikkate şâyân olan Koçu Valah nâmındaki Ulah ahâlî dahi iddi‘â-yı mevcûdiyete kıyâm eylemiştir.

Balkan Mes'elesi hallinin ne derece müşkil olduğunu tefhîm için sâlifü'z-zikr milel-i muhtelifenin hâl ve mevki'lerini alâvechi'l-ihtisâr irâ'e ve ta'rîf lâzımdır.

Osmânlı fâtihleri Şarkî Roma'yı teşkîl eden memâlike "Rûm" dedikleri gibi ahâlîsini dahi bu isimle tevsim ederler yalnız Balkan Şibh-i Cezîresi'nden ibâret olmayıp Asya sevâhilini dahi ihtia eden işbu memâlik sekenesinin beynlerindeki farka ol kadar nazar-1 ehemmiyet atfetmemişler ve İskender-i Rûm işbu memâliki istîlâ ettiği esnâda tâbi'iyetinde bulunan ahâlînin kâffesi Osmânlılarca Rûm addedilmişlerdir.

Roma'nın Şark İmparatorluğu'ndan sonra fütûhât-1 Osmâniye'den dolayı nüfûzu tenâkus edecek iken garibeden olarak bir ehemmiyet kesb eden Rûm Patrikliği tâbi'iyet-i Osmâniye'de kalan umûm re'âyânın riyâsetini der-uhde edip taht-1 idâre-i Osmâniye'de bulunan umûm ahâlî-i Hıristiyâniye'yi tevhîd için sarf-1 ikdâm eyledi. İşbu ikdâmda ifrât görüldüğünden Rûm papaslarının azametlerine karşı hâsıl olan nefret el-yevm ahâlî şarkılarında mezkûrdur. Bu sûretle mukaddeman mevcûd olan Bulgar Eksarhlığı'nın ehemmiyeti kalmamış idi. Geçen asırda Kaynç(?) nâm kimse ile beraber sâ'ir Avrupa erbâb-1 tedkîkâtı Bulgarlığı yeniden meydâna çıkardıklarından Bulgarlarca ayrıca idâme-i milliyet fikri uyanıp Rûm Patrikliği riyâsetine muhâlefet olunmağa başladığından fî 10 Mart sene 1870 târîhiyle ihsân buyrulan fermân-1 humâyûn mûcebince Bulgar Milleti taht-1 tasdîke alınmağla eksarhlığı Rûm Patrikliği'nden tefrîk edildi. İşbu târîhe değin Bulgarlar da dâhil olduğu hâlde bütün Makedonya ahâlîsi Rûm i'tibâr edilir idi.

Bulgar Eksarhlığı'nın büyümesine ve Bulgarların be-tahsîs Osmânl1-Rus Muhârebesi'nden sonra nâ'il-i emel olarak Emâret teşkîliyle terakkîlerine mukâbil Rûm papaslarından başka ahâlîsinin dahi galeyân-1 hiddetini mûcib olmuş olması tabî'îdir. Bulgarlar kendiliklerinden kalkıp Rûmeli-i Şarkî'yi Emâretlerine ilhâk ile kesb-i vüs'at ve kudret etmeleri mezkûr hiddeti son derece teşdîd eylemiştir. Bütün Yunanistan muvâzene da'vâsına başlayıp ma'lûm olduğu üzere resmen i'lân-1 harb vukû' bulmadan Teselya hudûdunda müsellah ihtilâf zuhûr etmiş ve Korana Muhârebesi'nin netîcesi Yunanlıların emellerini kesr eylemiştir.

Yunanlıların nefret ve adâvetleri yalnız Bulgarlara mahsûs olmayıp bu son vakitlerde be-tahsîs Ulahlara dahi teşmîl edilmiştir. Ulahlar Yunanlıların istiklâliyet muhârebâtında tamâmıyla Yunan sûretinde bulunmuşlar ve işbu muhârebelerde ifrâtla Yunan görünen kahramânlar Makedo Valah denilen Ulah kabâilinden idiler memâlik-i ecnebiyede yalnız ve büyük tüccâr olarak bulunan Yunanlılar dahi ekseriyetle Ulahlardandır. Bunların ayrıca bir millete mesnub oldukları geçen asrın doksan seneleri târîhinde Apostol Margreti nâmındaki ser-gerdeleri tarafindan meydâna çıkarılıp mu'ahharan Rûmlardan kendilerini tefrîk etmişlerdir. Romanya Kraliyeti Ulahlarla münâsebet-i milliyeleri var gibi görünüyotr ve ekseriyâ Roma muhâciri evlâdları ve yâhûd barbarların tazyîkiyle terk-i vatan eden İtalya muhâcirlerinden addediliyorlar. Kendi fikirlerince kadîm Arnavud kabâ'ilinden bulunduklarını söylemelerine nazaran Romalılardan Latinleșmiş olan Edirne ciheti ahâlî-i kadîmesinden olmaları muhtemeldir. el-Yevm şekil ve sîmâ ve melbûsât cihetleriyle civârlarında meskûn ahâlîden farkları ve ekseriyâ İtalyan'a müşâbihtirler. Aşağı derecede bulunaları câlib-i dikkat bir tarzda göçebe hâlinde bulunup biri yüksek yaylalarda ve diğeri münhatt ovalarda olarak iki nev` meskenleri vardır. Mayıs mâhının beşi olan Hızır-İlyâs günü karlar eridikten sonra latîf sûrette yeşillenmiş olan yüksek yaylalara gitmek üzere hareket ederler ve Teşrîn-i Sânî'nin yedisi olan Kâsım gününde yaylalarda idâre olunamayacak bir hâle gelince ovalara inerler. Yaylalardaki köyleri Alp köyleri misilli latîf ve ovalarda olan köyleri civâr köylere nisbetle zengîndir. Ma'lûmâtlarının Avrupa terakkiyâtıyla irtibâtı ziyâdedir. Bu husûsun sıhhatini bir seyâhat esnâsında nezdinde müsâfir kaldığım Maço Belediye Re'îsi'nin hânesinde bi'z-zât müşâhede ettim. Yeniden aranılıp bulunması îcâb edecek olan târîh-i millîleri için merakları çoktur. Târîh işbu milleti altıncı asr-1 mîlâdîde tuna'dan Yunanistan'a kadar imtidâd etmiş olan meşhûr Ulah Hükûmeti'ne rabt etmektedir. Mûsevî Benyamin Fon Toledo dahi Yunanistan şimâlinde olan Lamya'yı bir Ulah şehri olarak irâ'e ve oranın Ulahistan'a benzer bir manzara irâ'e ettiğini ve ahâlîsinin dahi Ulah isimlerinde olduklarını tasrîh ve dağlardan keçi gibi mahâretle gasb ü gâret için ovalara indiklerini beyân etmiştir. Ma'lûm olduğu üzere İkinci Bulgar Hükûmeti Ulah şeklinde olup Petro ve Aja ve Yovan nâmlarındaki büyük çarları Ulah sülâlesinden bulundukları rivâyet olunmaktadır. Latin İmparatorluğu dahi biraz müddet sonra hükûmet-i mezkûre taht-1 idâresine geçmiştir. Ulahlar Romanya ahâlîsiyle irtibarları bulunduğunu şiddetle hissederler ve Romanya Hükûmeti'nden sahâbet ve himâye 
beklerler ise de istiklâliyet-i milliyelerinin husûlünü ve yâhûd Romanya ile birleşmeği düşünmezler. Âkilâne olan fikirleri diyânet ve mekâtib cihetiyle terakkiyât-1 milliyelerini ileri götürmektir. Hükûmet-i Osmâniye bulunmadığı hâlde Makedonya'da bulunan milletler arasında gâ'ib olacaklarını bildiklerinden siyâseten Hükûmet-i Osmâniye'ye merbût bulunurlar. Bu irtibât ve i'timâddan dolayı Bâbıâli kendilerine müteşekkir ve Makedonya'da jandarma hey'etinin Hiristiyân kısmında el-yevm mevcûdları nisbeten ziyâdedir. Dersa'âdet Romanya Sefâreti'nin tavsiyesi üzerine vilâyât-1 mezkûre Ulahlarından otuz zât 1903 senesinden beri 1slâhât sırasında me'mûriyet-i mühimmeye ta'yîn olunmuşlar ve bir zât dahi milliyeti irâ'e etmek üzere müfettiş-i umûmîlik ma'iyetinde bulunmaktadır. Binâ'en-aleyh Ulahların milliyeti ol vakitten beri meydâna çıkmış ve fî 9 Mayıs sene 1905 târîhli fermân1 humâyûn ile Hükûmet-i Osmâniyece taht-1 tasdîke alınmıştır. Bu sûretle kendilerine kilise inşâ etmeleri ve mekteblerinde Romanya lisânının tekellüm ve tahsîl olunması ve nüfûs-1 mevcûdelerine nazaran meclis-i idârelerde a'zâlarının bulunması ve nüfûslarının a'zamî bulunduğu yerlerde kendilerinden muhtâr intihâb etmeleri hukûk ve salâhiyeti verilmiştir. Hükûmet-i Osmâniye meclis-i idâreleri idâre-i zâtiye husûsunda müsâ'adât-1 vefîrede bulunduğundan işbu hukûk ve salâhiyetlerinin terakkiyât-ı âtiyeleri için ehemmiyet-i azîmesi vardır. Fakat el-yevm Ulahları pek düşman ve küfran-1 ni‘met etmiş eşkıyâ addediyorlar.

1885 senesi muhârebesiyle Sırb azameti kırıldı ise de Bulgarların büyümesiyle Sırb misyonerler tekrâr uyandılar doksan senesi târîhine değin Sırblılar Makedonya ortalarında daha pek cânlı görünüyorlar ve Sirb nüfûzu da Vilâyât-1 Selâse'de Sirbiye imiş gibi terakkî ve tezâyüd etmiş idi. Târîhçe olan iddi‘âlarına nazaran mîlâdın yedinci asrında Bulgarların birinci def'a olarak geldiklerinde Balkan Şibh-i Cezîresi ahâlîsinin kısm-1 a'zamı Sırb idiyse de istîlâ edenler yerli ahâlîyi kendilerine uydurmak ve kendi unsurlarıyla birleştirmek yolunu mahâretle bulduklarından külliyetli nüfûs gelmiş zann olunmuştur. Bir de birinci def'a olarak Osmânlılara karşı çıkıp muhâfaza-i istiklâliyet için edilen muhârebelerde bulunduklarını Sırb ahâlîsi unutmamış ve ma'lûm olduğu üzere 1876 senesi Balkan'da bir büyük tebeddülât îkâ' 1 için netîcesinden Bulgarların en ziyâde müstefîd oldukları hamleyi Karadağlılar ile birlikte yapmışlardır. Sırb misyonerleri yeniden be-tahsîs eski Sırbistan'a ve Bosna-Hersek'e yayıldığı hâlde Bulgar idâresi idâre-i Osmâniye yerine geçecek olur ise beynlerinde imtizâcsızlığın eksik olmayacağı der-kârdır.

Kendi fikirlerince Balkan Şibh-i Cezîresi'ne en haklı vâris olduklarını zanneden milletlerden birisi de Ulahların kendilerine en yakın addettikleri Arnavudlardır. İşbu iki milletin Balkan Şibh-i Cezîresi ahâlî-i kadîmesinden bulundukları rivâyeti Arnavudların kuvvetini tezâyüd eder. Arnavudlar kendilerine zâde-gân ma"nâsına olan "İşkibdar" nâmını verirler. Bükreş'te "İşkibdari" nâmında intişâr eden cerîde işbu iki milletin menâfi'-i müşterekesi hakkında şâyân-1 dikkat makâleler ile Panslavizm savletine mukâbele etmektedir. Arnavud ile Ulah unsurları birleşecek olur ise Makedonya'daki milel-i rakîbenin en kuvvetlisi olurlar. Bir kısmı ortodoks ve bir kısmı İslâm ve bir kısmı Roma Katoliği olarak dînen olan tefrika Arnavudların za'fını muceb olmuştur. Arnavud kabâ'ili beyninde eşrâf ve bahâdır Meriditlerdir bunları Arnavudlar müttehiden ve müftehiran takdîr ederler. Arnavud darb-1 mesellerinden birisi "Hâlik-i yezdan milletleri dînlerden evvel yaratmıştır." ve bir diğeri "Kılıcın olduğu yerde îmân vardır" me’âlindedir Makedonya'da olacak Bulgar idâresinin İskender-i Yunanî tarafından zabt olunamadıklarını ve Ebû'l-Feth hazretleri cânibinden taht-ı idâreye alınamadıklarını der-hâtır eyleyen Arnavudlardan uzlaşmaz hasımlara tesâdüf edeceği derkârdır Avrupa'da Makedonya istikbâlinden bahs olunduğu sırada diğe unsurlara nisbetle a'zamını teşkîl eden Osmânlılardan kat'an bahs olunmaması fevka'l-âde şâyân-1 istiğrâbdır. Osmanlıların istatistikçe ehemmiyet vermemeleri böyle mühimm ma'lûmâtın meydâna çıkmamasına sebeb olmuştur. Kendileri neşriyâtta bulunmağı sevmezler ve ecânibin yanlıș anladıklarına ve yazdıklarına cevâb vermezler. Ve atf-1 ehemmiyetle müdâfa'a etmezler. Kendilerinde millet-i hâkime ihtisâsının bulunmasını kâfî görürler. $\mathrm{Bu}$ hâllerinden dolayı haklarında muzırr pek çok zann ve fikir tevellüd eylemiştir. El-Yevm memâlik-i şâhânenin mevcûd harîtalarının esâs-1 ekserîsi çok def'alar Hiristiyân hânelerinde müsâfir kalarak istikşâfât seyâhati eden Avrupalıların yaptıkları harîta müsveddelerinden alınmış olduğu nazar-1 dikkatten dûr tutulmamalıdır. Devleti Aliyye-i Osmâniye Erkân-1 Harbiyesi tarafindan hiçbir tedkîkât ve tashihatta bulunulmayarak aynen tercüme edilmiş olan Avusturya'nın geçen asır nihâyetinde yapılmış olan Balkan Şibh-i Cezîresi'nin 1/300000 nisbetinde olan büyük harîtası dahi ayn-1 usûl ve tarzda tertîb olunmuştur. İşbu harîtanın topograf işlerini yapanların memleketin ahvâl ve lisânına vâkıf olan Cenûbî Avusturya İslav milletlerinden oldukları der-kârdır. Bunlar tahsîsan Hıristiyân mevâki'i hakkında ma'lûmât zabt etmişlerdir 1887 senesinden bede' ile Devlet-i Aliyye Erkân-1 Harbiyesi'nde taht-1 idâremde yapılan 1/210000 nisbetindeki harîtanın tertîbinde İslâm ve Rûm köyleri arasında İslâm isimlerinde olarak def'aten şâyân-1 hayret mikdârda çok İslâm köyleri bulunduğu meydâna çıkmıştır. İhtirâz-1 mübâlağadan dolayı işbu harîtanın pek az intişâr etmiş ve İslâm ahâlînin mikdâr-1 nüfûsunu tahmîn hakkında herkesin zihninde yerleşmiş fikrin ber-taraf edilmemiş olması şâyân-1 te'essüftür.

Milel-i muhtelifeden İslâm ahâlînin Osmânlı nâmı tahtında bulundukları ve fetihten evvel bunların ekserinin Balkan Şibh-i Cezîresi'nde sâkin idikleri der-kârdır. Bizans Hükûmeti muhârebât-1 adîdeden dolayı ahâlîsi azalmış olan yerlere dâ'imâ muhâcirîn iskân etmek ve sâdık ve metîn me'mûrîn ile hârice karşı münâsebetleri bir siyâkta ahâlîyi beraber bulundurmak husûslarında şâyân-1 imtisâl mahâret ibrâz etmişlerdir. Asya ortasında bulunan Türkler Tuna üzerinden nakl olunarak memlikin garb askerî hudûdu civârında ve Selçukî üserâ-yı harbiyesi Teselya Ovası'nda ve Türk muhâcirleri Ohri civârında Uz Türkmenleri Mekadonya'da olan arâzî-i emîriyeye yerleştirilmişler ve Tatar ve Çerkes ve İslâm Gürcü ve Yörük ve sâ'ir kabâ'ili İslâm nâmı tahtında birleştirmişlerdir. Esâsen bir olan dînleri bunların cümlesini tevhîd eylediğinden işbu cem‘iyyetin milel-i sâ'ireye karşı siyâseten kuvvetli bir millet-i cesîme teşkîl etmekte olduğu hükm olunabilir.

Makedonya'nın istikbâli üzerine esâslı ve metîn hukûkları dahi bulunduğundan idâre-i Osmâniye yerine kâ'im olacak bir idârenin bunları ciddî sûrette dâhil-i hesâb etmesi lâzım gelir.

İşbu îzâhât-1 muhtasaradan müstebân olduğu üzere memleketin hâl-i hâzırı tebdîl edilecek olur ise ağleb ihtimâl sâlifü'z-zikr milletler yekdiğeri aleyhine kıyâm ederek bir 
cidâl-i umûmî vukû‘ bulup terakkî ve tevessü‘ ümmîdinde bulunan bir iki Hıristiyân milletinin mahvıyla netîcelenebilir. Milel-i mezkûreden hiç birisi diğerine karşı kendisini muhâfaza edecek kuvveti hâ'iz değildir. Bu bâbda hâ'iz-i kuvvet olmaları muhtemel olanların Bulgarlar olacağı şübhesizdir. Ohri'den bede' ile havâlîsini taht-1 idârelerine almış olan çarları Simon ile Samuel zamânlarındaki vekâyi‘ i târîhiyeyi der-hâtır etmekle beraber zahrlarındaki milletdâşlarının en kuvvetli ordularına istinâd ettiklerini bilmeleri bunlara ziyâde ümmîd-bahş olur. Bulgar zâbitân ve me'mûrîni indlerinde Makedonya büyük ehemmiyeti hâ'iz ve emâret ile işbu vilâyât beynindeki irtibât pek kuvvetlenmiş ve Bulgaristan'da kıyâm fikri takarrur etmiş olmağla "Bulgar tavşan avına arabasıyla gider" darb-1 mesellerinin hükmü mer‘îdir.

Fakat Bulgar tefavvuku Yunan unsuruna ve Arnavud Ulah ittihâdına mukâbele ve yâhûd daha millet-i hâkime olan Osmânlı muhâlefetini ber-taraf edebilmek için derece-i kâfiyede değildir. Milel-i sâ'irenin kâffesinin muhâlefetine karşı kuvvetinin gayr-1 kâfî olması ihtimâli ziyâdedir. Sâlifü'l-beyân mülâhazât Yunanlılar hakkında dahi cârîdir. Bunların dahi idâre-i hükûmet istihsâline teşebbüs etmeleri bir vahîm netîceye müncerr olur. $\mathrm{Bu}$ sûretle idâre-i Osmâniye'nin devâm etmesi tabî'î görünmekle beraber Mekadonya'nın sa'âdeti içinde en fầ'idelidir. İşbu maksadın husûlü için hükûmet-i müşârun-ileyhâya iki şey lâzımdır bu iki şey de ciddiyet ve şiddet ibrâzı ve bir kuvvetli ordunun vücûdudur. 1897 senesi vukû‘ bulan Osmânl1-Yunan muhârebesi Avrupa'nın cenûb tarafındaki memâlik-i şâhânede sükûn ve âsâyişin istikrârını bâdî ve hattâ Bulgar misyonerleri tarafindan bozulmayacak olursa iki devlet beyninde uzun müddet devâm edebilecek münâsebât-1 hasenenin husûlünü mûcib olmuştur. Ahîran kıta'ât-1 şâhâne ile müsâdeme eden gönüllü hey'etleri idâre-i Osmâniye aleyhinde bulunmayıp Avrupa'nın talebi üzerine yalnız Bulgar komiteleri tarafindan tazyîk olunan millet-dâşlarına mu'âvenet maksadıyla hudûdu tecâvüz etmişler idi. Atina'da müsellah ihtilâf ve müsâdemeden sonra hırs u tama' maksadına başlamak için kuvvetin kâfî olmadığı anlaşıldığından şimdiki hâlde sulh fikrinde bulunulmaktadır.

İşbu misâlde bulunan netîce şâyân-1 te'emmüldür. Muhârebeden çekinmeyerek ciddiyetle meydâna çıkmanın siyâsî karş1lıklara dâ'imâ hüsn-i te'sîri olduğu görülmüştür. Eğer 1903 senesi Sarakof idâresinde olan Bulgar eşkıyâsının şiddet ve kuvvet kesb ettiği ve emâret tarafindan mütemâdiyen mu'âvenet olunduğu sırada muhârebeye karâr verilmiş olaydı bugün Balkan Şibh-i Cezîresi'nde ağleb ihtimâl sulh u âsâyiş hüküm-fermâ bulunur idi. Fakat şimdiki hâlde Makedonya mevâki'inde artık silâh altında kuvve-i külliye bulundurmak ve ciddiyet ve şiddetle alay kumanda ettirmekten başka çâre yoktur. Sükûn ve âsâyiş mûcib-i 1slâhât âsâr-1 hasenenin husûlünü bâdî olursa da yalnız bununla mes'elenin halli te'mîn edilemez. Çünkü vâsıta-i âsâyiş âsâyiş istemeyenlere karşı hükümsüzdür.

Bu îzâhâttan Makedonya'ya bir Avrupalı vâlî-i umûmî ta 'yîni hakkında olan yeni teklîften bir netîce-i hasenenin çıkmayacağını derece-i kâfiyede müstebân olur. Bâbıâli ile irtibâtı bulunmayacak bir vâlînin kıta'ât-1 Osmâniye üzerine hakk-1 nüfûzu olamayacağından böyle bir vâlî-i umûmînin istihsâl-i kuvvet için milel-i muhtelifeden başlıca kangılarına istinâd etmesi lâzım geleceği su'âli tevellüd eder.

Ve Makedonya ahvâlini samîmî sûrette bilen bir kimse de işbu su'âle cevâb vermeğe borçlu olur.

Milel-i muhtelife ile irtibâtta bulunarak cümlesine hakkâniyet dâ'iresinde mu'âmele etmek emelinde sa'y ü gayret memnûniyet-i umûmiyeyi istihsâl edemeyecektir. Bâbıâli ile irtibâtı bulunacak vâlî-i umûmî taht-1 idâre-i Osmâniye'de olan şimdiki vâlîler ile askerî kumandanlarından fazla bir iş yapamayacaktır.

Bundan başka bir İslâm Avrupa i’tilâfının taht-1 nüfûzuna girecek olsa bile itâ'ati birinci derecede makâm-1 hilâfete müteveccih olur. Binâ'en-aleyh işbu yeni teklîf ile hâl-i hâzır şâyân-1 tezkâr sûrette ta'dîl edilemeyecektir. Bâlâda beyân olunduğu üzere milel-i muhtelife ahvâlinin müsâ'ade ettiği derecelerde dâhil-i memlekette sükûn ve âsâyişi muhâfaza edebilmeğe muktedir me'mûrîn yok değildir. Ve îfâ-y1 vazîfe için arzu ve gayretleri dahi ber-kemâl olup Avrupa'nın me'mûrîn-i Osmâniye'ye karşı ibrâzına hâhiş-ker olduğu sûi emniyeti mûcib meydânda bir şey yoktur. Me'mûrîn-i mezkûreden Almanya'da tahsîl etmiş erbâb-1 şiddet ve basîretten Rahmi ve Şükrü Paşaları ve kezâ Almanya hizmeti askeriyesinde bulunmuş olup Üçüncü Ordu-yı Humâyûn Müşîr Vekîli hayr-hâh ve terbiye-i dakîkayı hâ'iz Es'ad Paşa'yı ve Kosova Vâlîsi aliyyü'l-a'lâ Mahmûd Şevket Paşa'yı ve Siroz mevki‘inde Müşîr İbrâhîm Paşa'yı ve bir Yunan çetesinin bir eşkıyâ köyüne ta'arruz etmesinden dolayı Manastır'da olan me'mûriyetinden alınan aliyyü'l-a'lâ Hâdî Paşa'yı tezkâr ve şimdiki hâlde isimleri hâtıra gelmeyen diğerlerinin dahi bulunduklarını beyân ederim. Balkan Mes'elesi'nin olabildiği kadar müsâ‘id bir sûrette hallolunabilmesi me'mûrîn-i mezkûrenin hedef oldukları şikâyetlerden dolayı mes'ûl bulundukları Bâbıâli cânibinden kuvve-i zahriyeye nâ'il olmalarına ve dûçâr-1 su'ûbet ve müşkilât edilmelerine ve bununla da olamadığı hâlde cümlesinin me'mûriyetlerinden alınarak her şeyin yapılmış olmasına menûttur. El-Yevm müfettiş-i umûmî ve icrâsına bede' olunan ıslâhât için Bâbıâli tarafindan komiser bulunan Hilmi Paşa'dan başka me'mûriyet-i mezkûre için daha münâsibini bulmak mümkin değildir. el-Hâsıl balkan Mes'elesi lede't-tedkîk netîcesinin bundan on beş sene evvelîsi Viktor Berard nâm kimsenin "La Türkî é Elenizm Fon Tamporen"(?) ${ }^{10}$ nâm kitâbında münderic "Makedonya'da en müstakîm adliye ile en kat'î ve ciddî hukûk tetâbuk eder. Milel ve cemâ'ât-1 muhtelifenin usûl ve kavânîn-i mesrûdeye ri‘âyeti ancak Hükûmet-i Osmâniye'nin devâm ve bekâsıyla te'mîn edilebilir." ifâdesini ma'a-ziyâdetin hâ'izdir.

Avrupalıların haksız teklîflerinden ekseriyâ haklı olarak şikâyet eden Osmânlı kumandanlarına en nihâyet "Kuvvetli olun ki umûmun haklı mu 'âmelesine nâ'il olasınız" ihtârında bulunulmalidir.

fî 6 Nisan sene [1]324 [17 Rebî‘ü'l-evvel 1326/19 Nisan 1908-Pazar]

\footnotetext{
${ }^{10}$ La Turquie et I'hellénisme Contemporain
} 